Florida International University FIU Digital Commons

$11-1-2012$

\title{
Historiographic Metafiction and the Neo-slave Narrative: Pastiche and Polyphony in Caryl Phillips, Toni Morrison and Sherley Anne Williams
}

Christiane Hawkins

Florida International University, chawk003@fiu.edu

DOI: $10.25148 /$ etd.FI12112703

Follow this and additional works at: https://digitalcommons.fiu.edu/etd

\section{Recommended Citation}

Hawkins, Christiane, "Historiographic Metafiction and the Neo-slave Narrative: Pastiche and Polyphony in Caryl Phillips, Toni Morrison and Sherley Anne Williams" (2012). FIU Electronic Theses and Dissertations. 741.

https://digitalcommons.fiu.edu/etd/741 


\title{
FLORIDA INTERNATIONAL UNIVERSITY \\ Miami, Florida
}

\section{HISTORIOGRAPHIC METAFICTION AND THE NEO-SLAVE NARRATIVE: PASTICHE AND POLYPHONY IN CARYL PHILLIPS, TONI MORRISON AND SHERLEY ANNE WILLIAMS}

\author{
A thesis submitted in partial fulfillment of the \\ requirements for the degree of \\ MASTER OF ARTS \\ in \\ ENGLISH \\ by
}

Christiane Hawkins 
To: Dean Kenneth G. Furton

College of Arts and Sciences

This thesis, written by Christiane Hawkins, and entitled Historiographic Metafiction and the Neo-slave Narrative: Pastiche and Polyphony in Caryl Phillips, Toni Morrison and Sherley Anne Williams, having been approved in respect to style and intellectual content, is referred to you for judgment.

We have read this thesis and recommend that it be approved.

Nathaniel Cadle

Heather Russell

Steven Blevins, Major Professor

Date of Defense: November 1, 2012

The thesis of Christiane Hawkins is approved.

$\begin{array}{r}\text { Dean Kenneth G. Furton } \\ \text { College of Arts and Sciences } \\ \hline \begin{array}{r}\text { Dean Lakshmi N. Reddi } \\ \text { University Graduate School }\end{array}\end{array}$

Florida International University, 2012 


\section{ACKNOWLEDGMENTS}

I sincerely thank my thesis committee members and director for their assistance and encouragement. In particular, I am grateful to Dr. Steven Blevins for his guidance and patience throughout the past year. Dr. Nathaniel Cadle provided much needed advice and was always available and Dr. Heather Russell pointed me into the right direction more than once, thank you. I also extend a sincere thank you to Dr. Asher Milbauer for his endorsement in joining the Master's Program. Lastly, I thank Ryan, Vanessa and Edgard who kept me going when I was overwhelmed at times. 


\begin{abstract}
OF THE THESIS
HISTORIOGRAPHIC METAFICTION AND THE NEO-SLAVE NARRATIVE:

PASTICHE AND POLYPHONY IN CARYL PHILLIPS, TONI MORRISON

AND SHERLEY ANNE WILLIAMS
\end{abstract}

by

\title{
Christiane Hawkins
}

Florida International University, 2012

Miami, Florida

Professor Steven Blevins, Major Professor

The classic slave narrative recounted a fugitive slave's personal story condemning slavery and hence working towards abolition. The neo-slave narrative underlines the slave's historical legacy by unveiling the past through foregrounding African Atlantic experiences in an attempt to create a critical historiography of the Black Atlantic. The neo-slave narrative is a genre that emerged following World War II and presents us with a dialogue combining the history of 1970 - 2000. In this thesis I seek to explore how the contemporary counter-part of the classic slave narrative draws, reflects or diverges from the general conventions of its predecessor. I argue that by scrutinizing our notion of truth, the neo-slave narrative remains a relevant, important witness to the history of slavery as well as to today's still racialized society. The historiographic metafiction of the neo-slave narrative rewrites history with the goal of digesting the past and ultimately leading to future reconciliation. 


\section{TABLE OF CONTENTS}

CHAPTER

PAGE

1 INTRODUCTION: THE CLASSIC AND THE NEO-SLAVE NARRATIVE.........1

2 CARYL PHILLIPS'S CAMBRIDGE AND CROSSING THE RIVER..............23

3 SHERLEY ANNE WILLIAMS'S DESSA ROSE AND TONI MORRISON'S

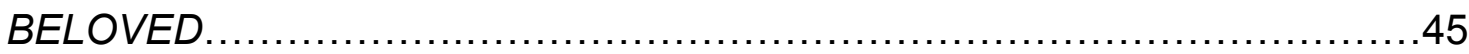

4 THE NEO-SLAVE NARRATIVE BEARING WITNESS $\ldots \ldots \ldots \ldots \ldots \ldots \ldots \ldots . \ldots \ldots$

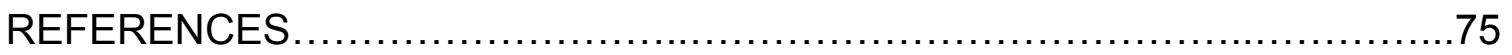




\section{CHAPTER 1}

\section{INTRODUCTION: THE CLASSIC AND THE NEO-SLAVE NARRATIVE}

Modern life begins with Slavery. Slavery broke the world in half, it broke it in every way. It broke Europe. It made everything in world war two possible. It made world war one necessary. Racism is the word that we use to encompass all this.

$$
\text { -- Toni Morrison }{ }^{1}
$$

The history of slavery and racism are inextricably intertwined, but slavery as an institution in Great Britain and America was the direct result of the capitalist development needed to provide the wealth to fund the industrial revolution. Slavery ruptured the world, yet the capitalist movement was determined to use racism and greed to justify the torturing, killing and breeding of human beings. None of these reasons can justify chattel slavery in America or anywhere else. From the days of slavery until the present time, historical records and literature have engaged with this atrocity. The earliest accounts of transatlantic slavery were travelogues written as early as the late seventeenth and the beginning eighteenth century by Europeans who ventured out to the Caribbean. ${ }^{2}$ Concurrently, the first slave narratives were published by former slaves who had escaped to freedom. The crimes committed in the name of slavery will never be redeemed. The past cannot be undone, but the future can be directed. The

\footnotetext{
${ }^{1}$ Excerpts from Paul Gilroy's Interview "Living Memory" with Toni Morrison, 1988 (from The Black Atlantic). (221).

${ }^{2}$ Aphra Behn's Oroonoko (1688) and several travelogues such as Matthew Lewis's or Mrs. Carmichael's (see bibliography)
} 
classic form hoped to lead to abolition while its postmodern cousin, the neo-slave narrative, underlines the historical legacy of slavery by unveiling the past. It does so by engaging critically with dominant histories and providing counter-narratives from within the African Atlantic tradition. Through forms of narrative experimentation such as pastiche and polyphony the neo-slave narrative thematizes forgiveness and reconciliation and strives for forgiveness for the present and reconciliation for the future.

My thesis addresses the meta-critical approach of the postmodern novel and moves way beyond the questions of accuracy, authenticity, or truth which preoccupied the traditional slave narrative. Instead, the neo-form engages with the criticism of slavery in itself and, while realizing that justice can never be done and a state of repair can never be reached, moving toward reconciliation facilitates the healing process. The neo-slave narrative scrutinizes the terminology and practice of slavery systematically and helps us understand, and eventually redress, part of the injustices of the past. The neo-form returns to the antebellum slave narrative by using the original literary form but concurrently developing its own argument about the political and cultural issues since the nineteenhundredsixties. The historical novel is the product of the purported subject it represents and the social and cultural conditions which were its cause as well as the literary form it employs. In other words, the neo-slave narrative invokes and then departs from the classic form so as to represent not the 
mainstream traditions but the experiences of the minorities, in this case the slave's. ${ }^{3}$ As such, the neo-slave narrative aims to represent the voices of those on the margin, including particularly ethnic minorities and women. By example of postmodern authors Caryl Phillips, Sherley Anne Williams and Toni Morrison I will explore how the neo-slave narrative historicizes both slavery and its legacy through formal innovation that continues to provide testimony to the lives and experiences of enslaved men, women and children from the era of the slave trade and plantation slavery.

I chose four novels to represent this genre: Cambridge and Crossing the River by Caryl Phillips because they exemplify some of the typical features for the neo-slave narrative such as pastiche ${ }^{4}$ while Phillips, true to his own background and heritage, introduces his readers to the British-Caribbean history of slavery. Neo-slave narratives often employ pastiche as a literary tool, and Henry Louis Gates states in his introduction of The Signifying Monkey that pastiche can either sustain an antecedent text or degrade an indomitable mode of representation of slavery. Phillips's novels are "tropological texts" ${ }^{5}$ To re-write history, he works repetition via pastiche into his novels. Pastiche as historicism fragmentizes Phillips's novels. According to Lars Eckstein bits and pieces of

\footnotetext{
${ }^{3}$ Ashraf H.A. Rushdy. Studies in the Social Logic of a Literary Form (7).

${ }^{4}$ Oxford English Dictionaries:

1. a. A novel, poem, painting, etc., incorporating several different styles, or made up of parts drawn from a variety of sources.

b. The technique of incorporating distinctive elements of other works or styles in a literary composition, design, etc.

${ }^{5}$ Henry Louis Gates. The Signifying Monkey.
} 
historical records are cut out of original sources and mixed as a "montage" into the novel to represent a bigger picture. ${ }^{6}$ My two other choices, Beloved by Toni Morrison and Dessa Rose by Sherley Anne Williams, focus more on the AfricanAmerican slave's history and the particular burden of enslaved women. These last two novels rely not so much on pastiche and involve African Atlantic features such as vocal polyphony and dialogism to invoke the past. As such, these novels are "talking books". 7 They re-write history via revision instead of repetition. Before I start to explore literary forms and devices of the neo-slave narrative, I will revisit the classic slave narrative and its immediate successors after the American Civil War.

The typical classic slave narrative emerged during the rise of the transatlantic abolitionist movement of the late eighteenth century. As testimonies to the brutality of life under slavery these narratives were intensely political documents. Several of the most widely read slave narratives of this era such as Equiano's Interesting Narrative are spiritual autobiographies of religious redemption pointing out the hypocrisy of Christianity versus the institution of slavery. These early forms of slave narratives were written by African Atlantic slaves from 1770 until the abolition of slavery in England and the slave trade in 1807. Authors such as Olaudah Equiano, Ottobah Cugoano and Venture Smith,

\footnotetext{
${ }^{6}$ Lars Eckstein. Re-membering the Black Atlantic: On the Poetics and Politics of Literary Memory. (69)

${ }^{7}$ Gates
} 
whose narratives emphasized slave trade and labor, are typical examples. As freeborn African men claiming royal descent or being close friends with the local chiefs, they were captured and subjected to slavery, then regained their freedom in the end. ${ }^{8}$

These early narratives provided readers with personal accounts of the experience of enslavement, transport from Africa to the colonies, the brutality of plantation labor and life and eventual escape from slavery. Further, many of these texts were told in the language of Christian salvation and assimilation to English standards of clothing, language and food. The main purpose of these early accounts lied in their accuracy, authenticity and relation of truth. The proof of authenticity was the governing principle of the traditional slave narrative and, consequently, the form of the narrative preceded the experiences. The tale was so preoccupied with showing proof that salvation became the main purpose, thus the narrative foreclosed who can speak within its forms and practices. Equiano, for example, kept recognizing his alleged sins and mistakes, tried to improve himself by living up to British expectations, kept stumbling again and repeated this process throughout his narration. His final salvation was to become a British subject and to be absorbed by his new homeland. Robert Stepto's Behind the Veil calls these first basic narratives "eclectic narratives" since their focus is on

\footnotetext{
${ }^{8}$ I am referring to the following narratives: Olaudah Equiano. The Interesting Narrative of the Life of Olaudah Equiano, or Gustavus Vassa, the African (1789). Ottobah Cugoano. Narrative of the Enslavement of Ottobah Cugoano, a Native of Africa (1787). Venture Smith. A Narrative of the Life and Adventures of Venture (1798).
} 
countless authenticating documents that are typically appended to the story and strive for authenticity. ${ }^{9}$ We know that, for example, Olaudah Equiano told us about his childhood in Africa and the Middle Passage; however, there are sources claiming he was born in slavery and thus never traveled on a slave ship. ${ }^{10}$ This knowledge would have destroyed the purpose of Equiano's tale as his story thrived on one truth based on authenticity and personal experience.

Other typical formal features of the classic slave narrative include an engraved portrait signed by the narrator and a title page proclaiming that the work is "Written by Himself" or "Related by Herself." ${ }^{11}$ Such claims of authentic authorship are followed by several prefaces, testimonials, or introductions written by a white abolitionist, editor, or author of the narrative confirming that the tale is an unaltered, true biography of the narrator. For the classic form the list of proof cannot be complete enough. The actual narrative typically starts with "I was born..." specifying a place but no date, shows fragmentary account of parentage, and describes a cruel owner with details of unjust mental or physical abuse. The tale then depicts a Christian slaveholder and the double moral standards of religion and slavery, followed by a description of the slaves' living quarters and their working conditions. The traditional form further illustrates a slave auction

\footnotetext{
${ }^{9}$ Robert Stepto. From Behind the Veil (5).

${ }^{10}$ Vincent Carretta. Equiano the African Biography of a Self-Made Man.

11 James Olney. I Was Born. Slave Narratives, Their Status as Autobiography and as Literature and other essays in The Slave's Narrative by Charles T. Davis and Henry Louis Gates Jr. (152153).
} 
separating families, then tells of the rising desire to escape slavery in a most dramatic way and finally reflects on slavery. ${ }^{12}$ Since these first tales were published by white abolitionists, the accounts do not necessarily reflect the slave's voice as too harsh criticism of the white society might have stopped the publication of the story. Henry Louis Gates refers to the early tales from 1770 to 1815 as "tropological texts" that work through repetition of tropes.

Following the first narratives published during the Atlantic slave trade were tales written between 1807 and 1865, from the end of the slave trade in 1807 until the abolition of slavery in the British colonies in 1834 respectively the end American Civil War in 1865. They were recounted by generations of enslaved men and women who had been born into slavery. Stepto calls these tales still basic but "integrated narratives". ${ }^{13}$ The authenticating documents are woven into the story instead of appearing in the appendix and become voices or characters in the narrative. The authors concentrated on their lives in bondage as plantation workers and house servants. Stepto lists narrations by Frederick Douglass and Harriet Jacobs as typical representatives for integrated narratives. ${ }^{14}$ The contents focuses on both physical and mental abuse, especially the practices of slave auctions and the resulting separation of families. Their perception of adaptation

\footnotetext{
${ }^{12}$ Olney

${ }^{13}$ Stepto. (5).

${ }^{14} \mathrm{I}$ am referring to the following slave narratives: Frederick Douglass. Narrative of the Life of Frederick Douglass (1845). Harriet Jacobs. Incidents in the Life of a Slave Girl (1861).
} 
and spiritual autobiography has changed to criticism of the colliding relationship between Christianity and slavery. The goal is no longer spiritual salvation but freedom per se. According to Stepto, a slightly more advanced narrative may be found in tales written by free (but still completely oppressed) African-Americans of the north, some composed before the American Civil War. In these stories the authenticating documents and strategies are totally subsumed by the tale and deliver a generic text such as Our Nig by Harriet Wilson. ${ }^{15}$

The two final groups of classic slave narratives represent the tales of progress in America after 1865 and the WPA slave narratives of 1936 until 1938. ${ }^{16}$ Both forms were less concerned with the depiction of the evils of slavery and more interested in the adjustments of former slaves in North-America to life in freedom. An example for a post Civil War narrative is Booker T. Washington's autobiography. Most of the WPA tales were recorded from interviews conducted by white field workers with former slaves and are thus not always documents that mirror the slave's voice.$^{17}$ Countless tales of this era have been published, drawing on personal experience from former slaves who remembered the days of their emancipation as children. With the last personal memories and experiences of former slaves the era of the classic slave's narrative concludes,

\footnotetext{
${ }^{15}$ Harriet Wilson. Our Nig (1859).

${ }^{16}$ Booker T. Washington. Up From Slavery. (1901). In the 1930s the Works Progress Administration sponsored a Federal Writers' Project dedicated to chronicling the experience of slavery (Encyclopedia of American History, 7th Ed., Jeffrey B. Morris and Richard B. Morris, eds., 1996).

${ }^{17}$ Charles T. Davis and Henry Louis Gates, Jr. The Slave's Narrative. (42)
} 
what follows is fiction eventually leading to the neo-slave narrative. Zora Neale Hurston's Their Eyes Were Watching God (1937) is a fictional narrative which meant to reject Racial Uplift efforts. Gates describes these narratives as "speakerly texts" because the spoken word, i.e. discourse, is written in vernacular dialogue versus platform English. ${ }^{18}$ Later novels such as Richard Wright's Native Son (1940), Margaret Walker's Jubilee (1966), Alice Walker's The Color Purple (1970) and Ernest Gaines's The Autobiography of Miss Jane Pittman (1971) display features of modernism respectively postmodernism and describe historical experiences based on relatives who were born into slavery. Gates refers to these novels as the "talking texts" which is his term for the "doublevoiced" discourse in black text, in this case to lend a black voice to a white text. This postmodern novel is also known as the neo-slave narrative.

As demonstrated above, we find slave history and fiction in the form of narratives and novels from the beginning of the Atlantic trade, throughout the Civil War, the Harlem Renaissance, the thirties and forties; however, slavery in literature hit a peak when the neo-slave narrative was born. This modern form of slave narrative emerged roughly following World War II and tells a fictional versus biographical or auto-biographical account while drawing upon both the history and form of the early slave narrative. The stories do not strive on individual experience any more, but are based on collective history and multicultural backgrounds. The themes of conversion to Christianity and freedom from

${ }^{18}$ Gates. The Signifying Monkey. 
slavery have been replaced by secular or other religious traditions. Freedom does not mean assimilation into the dominant culture but stands for the right to personal freedom. The neo-slave narrative identifies predominantly AfricanAmerican literary traditions with their own social order and presents us with a dialogue that combines history with the time span from the sixties to the nineties.

The term originates with Bernard W. Bell in his book The Afro-American Novel and its Tradition. Bell describes "neo-slave narratives as residually oral, modern narratives of escape from bondage to freedom". ${ }^{19}$ The tales make use of oral forms of African traditions - such as myths and legends - and provide us with insight into power and knowledge underlying the writing of history. Thus, they make the connection between the oral culture of Africa and the written word of the western world. Since the 1987 publication of Bell's work, the definition has included a broader set of texts than his original description could have expected: the neo-slave narrative presents some of the most compelling fiction written over the past fifty years and includes texts set in the era of slavery, immediately after the Emancipation, during the Reconstruction and extends to the present. Crossing the River is a perfect example as the novel covers 250 years pertaining to the era of the slave trade, slavery in the British colonies, freed slaves right after the American Civil War, descendents of American slaves in England during WWII and ending in the late twentieth century, the time Phillips wrote the novel.

\footnotetext{
${ }^{19}$ Bernard W. Bell. The Afro-American Novel and its Tradition (289).
} 
The neo-slave narrative originates in the social, intellectual and racial circumstances of the sixties. During this time the historiography of slavery experienced an intellectual shift in the study of American history. The modern American slave narrative is the expression of African-American views on American history and evolved from the loss "of a racially specific oral tradition" which was based on story-telling as well as music, blues in particular. ${ }^{20}$ Toni Morrison, for example, claims that for the longest time music had been a healing source for African-Americans (until it became contemporary music for everyone and was no longer exclusive for the black community). ${ }^{21}$ Morrison further states that she writes her novels in a way that is irrevocably black because they are firmly rooted in her own culture and her own African-American ancestry. The debate of American history by re-visiting the past and the political significance thereof at the time (1960 until 1990) is expressed in fictional work and presents the slave's respectively the African-American voice. ${ }^{22}$ The neo-slave narrative's authors were part of that generation and as such pushed to change social and cultural circumstances. By writing their novels they returned to their ancestry and - as much as their predecessors used the slave narrative to abolish slavery employed the neo-slave narrative to induce changes to their contemporary society by turning history upside down. The neo-slave narrative does not show

\footnotetext{
${ }^{20}$ Rushdy (23).

${ }^{21}$ Gilroy. The Black Atlantic (219).

${ }^{22}$ During the Civil Rights movement (60s) and the Black Power era (70s/80s).
} 
any romanticized nostalgia, but a critical examination of history aimed to ignite political resistance.

In this thesis I seek to understand how the contemporary counterpart of the classic slave narrative draws, reflects or diverges from the general conventions of the slave narrative. The neo-slave narrative reflexively and retrospectively challenges our ideas about the demand for "truth" in the early slave narratives. ${ }^{23}$ In order to show how the neo-slave narrative is trying to achieve historical justice for the injustice of slavery, this thesis will establish how form, literary style and thematic relevance rely on the classic slave narrative and how historical fiction can try to get one step closer to forgiveness for the suffering of generations of slaves and their descendents, eventually gaining some sort of reconciliation for future generations. While the classic slave narrative strived to "affirm the former slave's authorship of his tale" and tried to verify as many "facts" as possible and as such aims to establish authenticity, the neo-slave narrative does not make any such efforts. On the contrary, often times "[...] the startling absence of any commentary about the author may be a rhetorical silence that abets the persona's own well-calculated omissions". ${ }^{24}$ By not claiming to tell a true story, the neo-slave narrative becomes by no means pure fiction. As mentioned earlier, supposed that Equiano borrowed a collective experience to

\footnotetext{
${ }^{23}$ The main focus of the early slave narratives was to establish authenticity (see Stepto's definition).

${ }^{24}$ Stepto (98).
} 
include critical parts of any slave narrative such as the abduction from Africa and the Middle Passage, his narrative may not reflect his personal account but still relates history and tells some sort of truth, even if it is somebody else's. This knowledge would have destroyed Equiano's credibility, but does not matter in the neo-slave narrative which acts similarly by invoking awareness and remembering the past, yet never claiming authenticity.

By scrutinizing our notion of truth, the neo-slave narrative remains a relevant and important witness to a racialized society deeply rooted in the era of slavery. It does so by allowing us to get insight into the past, a process that Mikhail Bakhtin calls "reaccentuation of the past" ${ }^{25}$ Bakhtin refers to Russian history (and novels relating to it) while reaccentuation in the neo-slave narrative points out and clarifies images of the history of slavery - images that are vivid and strong enough to let us re-visit the past of slavery and will not let us forget. The postmodern authors do not present us with only one truth, but truths depending on the perspective of every narrator who bears witness to the same event from a different angle. These authors "approach the institution of slavery from a myriad perspectives and embrace a variety of styles of writing: from realist novels grounded in historical research to speculative fiction, postmodern experiments, satire, and works that combine these diverse modes" ${ }^{26}$

\footnotetext{
${ }^{25}$ Mikhail Bakhtin. The Dialogic Imagination (419-421).

${ }^{26}$ Valerie Smith. Neo-slave narratives. The Cambridge Companion to the African-American Slave Narrative.
} 
Robert Stepto defines the classic tales (that the postmodern authors fall back on) as "authenticating narratives" by describing the story as "subsumed by the authenticating strategy"; as such, the classic slave narrative becomes the authenticating document for the contemporary novel. ${ }^{27}$ According to Stepto the neo-slave narrative displays considerable control of the narrative by the author while the writers of the earlier eclectic and integrated narratives showed a compelling lack of control because they were too preoccupied to prove their stories were true. One might think of these contemporary texts as the slave narrative's modern siblings, narratives reflecting on historical settings, persons and events of the era of transatlantic plantation slavery and the slave trade itself.

The early slave narrative is typically linear while its postmodern relative often differs in form and style by employing non-linear, circular and multi-layered voices. Consequently, through a multitude of perspectives, the "narrative does not 'represent' a (real or fictive) story, it recounts it" and insomuch informs its reader about possible scenarios by re-writing history. ${ }^{28}$ Even though we find the key tropes of the classic slave narrative in the postmodern sibling, the neo-slave narrative is a synthesis of aspects from both history and fiction. Stepto expresses this thought in the introduction of his book. He writes that the neo-slave narrative "might best be called a history or fiction of the historical consciousness of an

\footnotetext{
${ }^{27}$ Stepto (Chapter 1).

${ }^{28}$ Gérard Genette. Narrative Discourse Revisited (42-43)
} 
Afro-American art form - namely, the Afro-American written narrative" ${ }^{29}$ Stepto refers to African-American literature in particular, but there are approaches by Linda Hutcheon and Hayden White to discuss postmodern literature and its relation to history in a more general way.

My attempt tries to apply historiographic metafiction to the neo-slave narrative in particular. Historical fiction draws on historical events introducing fictional characters while fictional history blurs the borders between true events and lives of the past; in other words, as long as the narrative is relevant and plausible, it imposes meaning to the past. Linda Hutcheon's A Poetics of Postmodernism specifies postmodern novels as historiographic metafiction inasmuch as she defines these novels as recognizing the past by critically examining events, persons and records while wrapping the findings with fiction. ${ }^{30}$ Hutcheon's argument builds on the notion that both history and fiction aim to make us comprehend the past. She states that postmodern writing - and the neo-slave narrative belongs to this category - triggers two simultaneous events. "It reinstalls historical contexts as significant and even determining, but in so doing, it problematizes the entire notion of historical knowledge". ${ }^{31}$ According to Hutcheon, historical knowledge is not necessarily "genuine", but subjective to the

\footnotetext{
${ }^{29}$ Stepto $(x)$

${ }^{30}$ Linda Hutcheon. A Poetics of Postmodernism (Chapter 6).

${ }^{31}$ Hutcheon (89).
} 
author's views. Historical knowledge also depends on the context such as values of the past in culture and social class.

Contrary to Hutcheon's view, Hayden White's work is suspicious of the act of historiography, but admits that it takes present views and limitation into account and results, at times, in a certain "avowed provisionality and irony". ${ }^{32}$ White's claim is that re-visiting the past, whether in fiction or facts, could make us understand history. His concern is to discuss History and not historiographic metafiction which he sees as a way to access history through emplotment. The past cannot be destroyed or denied, however ugly it may have been. Factual institutions such as slavery cannot be forgotten and in order to reach a state of reconciliation, comprehension precedes forgiveness. This illustrational approach of history helped the neo-slave narrative become so popular. In Tropics of Discourse, Hayden White claims that writing fiction about historical events does not change the reality of these events. Historical fiction as such illustrates history and past events by shaping them, putting them into perspective and familiarizing the reader with them. Fictional elements glue historical facts together and as such work to "emplot" history. According to White history is never unambiguous or accurate, because nobody can go back in time and literally re-visit the past. Our visits can only be imaginary. In The Content of the Form White re-affirms his former opinions. By his comparison of so-called facts in the form of annals or the shape of chronicles and then historical narratives, he prefers the narrative

\footnotetext{
${ }^{32}$ Hayden White. Tropics of Discourse.
} 
because it relates history by creating an understanding and presenting "finished events", not just fragments without beginning, plot, or conclusion.

A historical narrative does not fall apart, the reader can relate much better than to a list of facts or events. The narrative captures the reader's attention and interest in a more memorable way. However, historical novels require some moral judgment and thus need background information about the society, the laws, or even the religion of the people and their period of time. In other words, White admits that if the past is merely stated by random facts, it is difficult to remember. Relation to bygones becomes easier with a connection such as reasons for certain events. White compares the historical narrative to a "therapeutic process [which] is an exercise in the refamiliarization of events that have been defamiliarized". ${ }^{33} \mathrm{~A}$ historical event as such is not of value, it is neutral, but connected to fiction the event becomes meaningful. As long as fiction is not obvious and stays reasonable, it helps illustrate the past. If I apply this reasoning to novels such as Dessa Rose, Beloved, Cambridge and Crossing the River, they become relevant to history because the fictional protagonists could have lived their lives as described in the stories. Their assumed destinies make it easy to relate to the past (slavery) and its consequences, in this case the reason for still strained relationships between black and white Americans.

I agree with White that as long as fiction is plausible, it makes historical events more memorable and more easily accessible. For both White and

${ }^{33}$ White. Tropics of Discourse (87). 
Hutcheon the so-called facts of history are not the most important or deciding factor in how history is depicted or understood, but how the facts are "to be described in order to sanction one mode of explaining them rather than another" ${ }^{34}$ Historiographic metafiction is contradictory as there is a lot of tension about its validity. There is no dialectic between the historians and the fiction writers; however, when I read the neo-slave narrative as historiographic metafiction, I am not able to tell the fiction and the historical classics apart. The stories are plausible and hence confirm Hutcheon and White in their claim that metafictional novels help us explain history and keep certain events and persons relevant and their memory alive. Hutcheon's historiographic metafiction becomes useful for capturing the formal approaches to narrative and fictional work that the neo-slave narrative's authors are doing. Nevertheless, history and re-visiting the past require also the comprehension of the other, the non-western and African understanding of past and present events.

In an attempt to fight the general willingness to forget about slavery in Africa and America, Saidiya Hartman combines and interweaves historiography, autobiography, travelogues and literary criticism in Lose Your Mother (2007). Her effort supports any neo-slave narrative, and one might call the work itself a postslave narrative as Hartman analyzes the view people in Ghana had on slavery. Unlike the western interpretation, slavery is a taboo and a death like state. ${ }^{35}$ "The

\footnotetext{
${ }^{34}$ Hutcheon (99).

${ }^{35}$ Saidiyah Hartman: Lose Your Mother (155).
} 
Dead Book", a chapter in Saidiya Hartman's Lose Your Mother, travels the Atlantic slave route and talks about an untold story. It provides us with insight to the slave's history through the absence of a slave girl, a girl who died on the Middle Passage and whose murder leaves a gap in history: a girl who chose death over enslavement. Hartman attempts to recover the girl's existence with the help of the historical records of the trial of the slave ship's captain. She would have lain forgotten at the bottom of the Atlantic had the trial not recorded her death.

Hartman's book is another example of how history can be remembered and kept relevant in order to try to attain justice for the victims of slavery. I would not call her attempt a neo-slave narrative as she combines the past and her own "travelogue" and experiences. But Hartman, who literally returned to Ghana to shed light on her own history, discovered that the Ghanaians preferred for the ones taken across the ocean to forget their roots. "Never did the captive choose to forget; she was always tricked or bewitched or coerced into forgetting" ${ }^{36}$ She continues that the slave in America was in a similar situation, "a slave without a past had no life to avenge", one reason why slave owners tried to erase their slaves' memories. Since slavery was a state of death, the act of self-destruction was preferable to suffering in slavery, a choice that far too many made during the Middle Passage or for their children born in slavery (see chapter three).

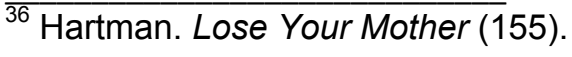


Hartman's essay Venus in Two Acts further zooms in on the unspeakable violent torture of slaves during the Middle Passage and their choice to die rather than endure. Hartman re-visits and revises her earlier account of Venus's death in "The Dead Book" as an attempt to redress this violence by giving a full description that leaves nothing to the imagination of the reader. She also informs that "there is not one extant autobiographical narrative of a female captive who survived the Middle Passage", an indication as of how many female slaves were raped, tortured and ended up dead without a trace. ${ }^{37}$ Two girls had died at the hand of the slaver's captain, and only one was accounted for in "The Dead Book". But not telling a story means not giving the slave a voice. The past is not recoverable, but according to Hartman, the recounting of Venus's death is the only way to remember her since her death is the only record we have of her. Hartman did not want to challenge the archives that mention only one girl because "[h]istory pledges to be faithful to the limits of fact, evidence, and archive, even as those dead certainties are produced by terror". ${ }^{38}$ Hartman cannot give Venus a voice, but she can write a "history written with and against the archive" and as such try to redress the terrors of the Middle Passage. ${ }^{39}$ Seen from this perspective, her attempt can be aligned with the purpose of the neoslave narrative. Hartman's study of African and Western concepts provides some

\footnotetext{
${ }^{37}$ Hartman. Venus in Two Acts (3).

${ }^{38}$ Venus in Two Acts (9).

${ }^{39}$ Venus in Two Acts (12).
} 
of the background we need to understand the neo-slave narrative and the perception of death per se from the slave mother's vision.

The neo-slave narrative is defined by contents and form, but even more by influences through cultural background and language. Henry Louis Gates claims that African traditions and values crossed the Atlantic with every slave who survived the Middle Passage. Each African man or woman was accompanied by Esu-Elegbara who carried the ghosts of Africa in form of songs, traditions and beliefs to the New World. ${ }^{40}$ These influences were present in every slave's life and story. In Legba's Crossing Heather Russell suggests that African Atlantic writers not only rely on postmodern and modern Western European forms, but are also engaged in fissuring History and foregrounding the power dynamics involved in its production. According to Russell, the neo-slave narrative of the eighties and nineties distinguishes African Atlantic tradition as "energized by ruptures, fissures, and formal departures that fundamentally challenge Western logocentricity". ${ }^{41}$ As such the Legba Principle interrupts, disrupts and erupts Euro-American literary convention. ${ }^{42}$ The neo-slave narrative written from this perspective of African Great Time and the Legba Principle employs multiple voices, is set in various times combining past, presence and future into one big ocean of time and unites remembrance and history. The polyphony of the neo-

\footnotetext{
${ }^{40}$ Gates. The Signifying Monkey (Introduction).

${ }^{41}$ Heather Russell. Legba's Crossing $(3,12)$.

${ }^{42}$ Legba is the God of crossroads
} 
slave narrative works via rupture as voices interrupt other voices. They help explain why not all enslaved men or women could be intimidated by the Middle Passage or their masters and ended preferring death over slavery. Russell's approach is present in all four of the novels I analyzed in this thesis. Hartman and Russell (via Hutcheon and White) help push the neo-slave narrative and the way it writes history to the idea of redress and reconciliation. 


\section{CHAPTER 2}

CARYL PHILLIPS'S CAMBRIDGE AND CROSSING THE RIVER

Caryl Phillips was born in Saint Kitts in 1954. His parents moved to the United Kingdom when he was only a few weeks old. He grew up in England, graduated from Oxford University and then returned to the West Indies for about two years. Phillips went back to England and worked there for several years before choosing to live in New York in the nineties. He is the author of several novels and plays, most of which are concerned with Caribbean, American and British history and slavery. ${ }^{43}$ Caryl Phillips, who himself is a descendent of Caribbean slaves, stresses the survival of slaves and their sons and daughters. With this endeavor in mind he abides by the main purpose of the neo-slave narrative: remembrance of the injustices of slavery and eventual reconciliation. The large scale immigration of British Caribbean subjects after WWII with the purpose to rebuild England left many of the immigrants disillusioned, especially the second generation who felt British but was not accepted as such by the white majority. Inspired by writers such as Richard Wright and later Samuel Selvon, Phillips provides a history of second generation black immigrants (such as himself) from the former colonies in the Caribbean and Africa. ${ }^{44}$ Phillips focuses on the history of slavery in the British Caribbean and immigration from the Caribbean and explains why he is doing so in a 1994 interview: "But what I find in

\footnotetext{
${ }^{43}$ www.carylphillips.com

${ }^{44}$ Richard Wright. Native Son (1940) and Samuel Selvon. The Lonely Londoners (1956).
} 
America - like the rich, strange, fertile relationship between those of African origin and mainstream society - is interesting, but it's not me. My primary axis of frustration is what happens between the Caribbean and Britain - particularly Britain ... (my ellipsis). If people say I'm British, I say fine; if they say I'm Caribbean, I say fine - because I'm both". ${ }^{45}$ True to his statement, Phillips provides us with the history of Caribbean slavery and its consequences for Britain's younger past, presence and future. Phillips concentrates on the past as a source for the British contemporary society integrating black British subjects by building on remembrance and hoping for future reconciliation. In doing so, Phillips rejects to see the perception of blacks only.

Caryl Phillips's approach to the neo-slave narrative as a call to remembrance and redress and an invitation not to forget or dismiss the cruelties of slavery keeps his novels relevant. As historiographic metafictional novels they reinstall and relate historical information. In Cambridge (1991) and Crossing the River (1993) Phillips draws predominantly on classic slave narratives such as Equiano's Interesting Narrative as well as historical travelogues such as Matthew Lewis's Journal of a West India Proprietor. His main intertextual device is pastiche. Equiano's tale is - according to Vincent Carretta - a mixture of Equiano's personal history and most likely fictional history. ${ }^{46}$ Phillips's two novels

\footnotetext{
${ }^{45}$ Maroula Joannou. "'Go West, Old Woman': the radical re-visioning of slave history in Caryl Phillips's Crossing the River."

${ }^{46}$ Vincent Carretta. Equiano the African Biography of a Self-Made Man (Preface).
} 
I am discussing, however, are historical fiction. We can trace historical and autobiographical passages of travel journals of the seventeenth and eighteenth century, which Phillips artfully weaves into his novels. Pastiche is a postmodern stylistic device of mixing and mashing which defines an imitation of other artists, styles, or periods to help create an aura of a different society, culture, or time. Employing pastiche is Phillips's way to create a time relevant setting of his novels as well as creating a way to disrupt the official discourse and fragmentize his novels. Gates would most likely call Phillips's narratives tropological texts because he works via repetition through his extensive use of pastiche.

By tapping into various sources of recorded history and then wrapping them in fiction, Phillips complies somewhat with what Linda Hutcheon calls historiographic metafiction. Hutcheon describes historical metafiction as novels recognizing the past by referring to actual events, persons and records while enveloping the findings with fiction. History is perceived as the past influencing the present. In Phillips's two novels the past is a chorus of all the voices and generations of slave history trying to tell their story and lead the way to reconciliation for future generations. ${ }^{47}$ While Cambridge is more submerged in the past, Phillips involves the future at least in one of his characters (Travis) in Crossing the River. According to Gail Low "the movement from Cambridge to Crossing the River is precisely one where history is perceived of as a redemptive

${ }^{47}$ Ref. African concept of Great Time 
act: the past is seen as our partners in future".$^{48}$ The form of historical metafiction allows the past to partner with the future. The pastiche of Phillips's historiographic metafiction allows for the repetition of history. The cutting and mixing chops history up. Little bits of pieces of historical archive and fiction are puzzled together in order to put some sort of social justice to work.

Crossing the River relies on the classic slave narrative. The first half of the book is divided into three parts and employs pastiche as a tool to "undo" the official discourse by deconstructing it. Part I is the slave narrative describing the enslavement of the three main protagonists. Part II illustrates the life of the captured slaves in America and Part III tells about the Middle Passage and is somewhat detached from the novel's slaves' destinies. The depiction of crossing the Atlantic consists of travelogues and letters of an original slave ship's captain, recorded in 1752. The second half of the novel uses the technique of stream-ofconsciousness pertaining to 250 years of African Atlantic history and reveals the survival of a slave's descendent who serves as a soldier for the American Army in England during World War II. He bears the same name, Travis, as the African sold into slavery in the prologue more than 200 years earlier. The soldier's son Greer is the only cue to hope for a better future as he is the only descendant of African heritage to survive in the New World.

\footnotetext{
${ }^{48}$ Gail Low. "'A chorus of common memory': slavery and redemption in Caryl Phillips's Cambridge and Crossing the River."
} 
Cambridge is also divided into three parts, framed by a prologue and an epilogue. As his predominant literary device Phillips employs pastiche which, in this case, interrupts the narration by giving the reader little pieces of information at a time. Part I talks about an English woman, Emily, who seeks refuge on her father's plantation. It draws heavily on travelogues and journals of the nineteenth century. Some of the similarities are striking. For example, Emily seems very interested in the different shades of black. Her intense distinctions between the mixed-race people of color are an exact copy from Matthew Lewis's 1834 travelogue. ${ }^{49}$ Also, when Emily encounters her visit to a rum production site, she describes the process from the sugar cane field to the distillery. Phillips's depiction is copied, verbatim, from Lewis's Journal of a West India Proprietor. ${ }^{50}$ Stella, Emily's house slave, describes obeah using words lifted from Mrs. Carmichael's travelogue. We also find passages lifted almost word for word from Janet Schaw's travelogue. ${ }^{51}$ By letting Stella, who is a slave, assume the descriptions from the travelogues, Phillips "un-does" the authenticity of the travelogues. The illustration of "lazy or ill-disposed negroes" and "erect and wellformed" people due to their lack of tight clothing is taken from Mrs. Carmichael's

\footnotetext{
${ }^{49}$ Matthew G. Lewis, Esq.MP.: Journal of a West India Proprietor Kept During a Residence in the Island of Jamaica. 1834. (106-107) and Cambridge (53)

${ }^{50}$ Journal of a West India Proprietor. 1834. (86-88) and Cambridge (52-53).

${ }^{51}$ Janet Schaw. Journal of a Lady of Quality; Being the Narrative of a Journey from Scotland to the West Indies, North Carolina, and Portugal, in the Years 1774 to $1776(112-113)$ and Cambridge (74-76).
} 
journals. ${ }^{52}$ Several descriptions of Caribbean foods are copied straight from Lady Nugent's journals. ${ }^{53}$ According to Lars Eckstein, Phillips employs more than twenty historical sources for Emily's narrative alone ${ }^{54}$ While Emily's journal in itself is fictional, it is mixed with and built from historic journals and travelogues of the late eighteenth and early nineteenth centuries. Eckstein writes in his essay:

Caryl Phillips used significantly more texts in the composition of Cambridge than Olaudah Equiano's Narrative and the journals of Lady Nugent, Mrs. Carmichael and "Monk" Lewis. There are at least twenty sources that Phillips integrated into the fabric of his narrative. In an appendix to this study, I have compiled a considerable number of source-passages which correspond to passages in the novel; these are listed in the chronological order of their appearance. Together, they cover about twenty per cent of the body of text in the three parts of Cambridge. The true percentage of montage, I assume, is considerably higher than that $[\ldots]$

Part II is also imprinted by pastiche, but follows the pattern of the classic slave narrative described earlier and relates the story of an African named Olumide, who was captured and enslaved, renamed Cambridge, became a free man after

\footnotetext{
${ }^{52}$ Mrs. Carmichael. Domestic Manners and Social Condition of the White, Coloured, and Negro Population of the West Indies (205) and Cambridge (34-35).

${ }^{53}$ Maria Nugent. Lady Nugent's Journal Jamaica One Hundred Years Ago.

${ }^{54}$ Lars Eckstein. Re-membering the Black Atlantic: On the Poetics and Politics of Literary Memory.
} 
the death of his master, traveled to England where he became an advocate for abolition, then was re-captured and sent to the West-Indies as an enslaved man again. In this part II pastiche works as a disruptive element by yanking Olumide from one place to the next. Part III is only a few pages long and is also pastiche, however, it copies an official record such as a trial record and as such ruptures the text. Cambridge employs pastiche to rewrite the archive by presenting two opposing facets on the view of slavery, one European and one African.

Evelyn O'Callaghan states in her essay about Cambridge that Phillips's work constitutes self-conscious fiction insomuch as "it is a pastiche of other narratives [which] have been read as historical reconstructions" by West Indian writers. ${ }^{55}$ Phillips weaves large passages of original historical journals into his novel and, according to O'Callaghan, "rewrites the European record of the West Indies". As such, Cambridge reveals its matrix in historical narratives and only wears fiction as a mask. By using historical sources for his narrative, Phillips's language provides for a linguistic and geographic atmosphere of the past. According to Robert Stepto, Phillips employs the "key tropes which form the AfroAmerican literary tradition" ${ }^{56}$ Emily's story takes us back into the past and history becomes alive. Phillips use of pastiche repeats history many times over in his narrative.

\footnotetext{
${ }^{55}$ Evelyn O'Callaghan: Historical Fiction and Fictional History: Caryl Phillips's Cambridge (1).

${ }^{56}$ Stepto (96).
} 
Part II relates the life of Cambridge, a slave on Emily's father's plantation and gives him the opportunity to tell his story from the slave's perspective. The tale follows the pattern of a typical classic slave narrative as introduced in chapter one of this thesis. Part II is written in the first-person voice of this story's protagonist, Cambridge. While he is a fictional character, Phillips draws heavily on Equiano's narrative, both on contents and language. Phillips employs Equiano's narration to invoke the past and let us enter the mind of a slave. But at the same time Phillips's use of pastiche condenses and strips Equiano's story of its authenticity and as such disrupts the historical discourse.

Cambridge talks about his faded image of Africa, which he calls uncivilized: "Many natives in my home are canting, deceitful people about whom one must exercise great caution". ${ }^{57}$ He remembers his African name, Olumide, and recalls being captured by Christians before he turned fifteen. Later, during the march from the native village to the coast "[n]ative conversation was forbidden and punishable by the lash", a direct quote from Equiano, as well. ${ }^{58}$ Endurance of the Middle Passage, the break with Africa and the conditions on the slave ship are also leaning heavily on Equiano's narrative ${ }^{59}$ Cambridge experiences the "making of a slave": "Such malice as these men of very indifferent morals exhibited, I had never witnessed among any people. [...] These

\footnotetext{
${ }^{57}$ Cambridge (133).

${ }^{58}$ Cambridge (135).

${ }^{59}$ Cambridge (137).
} 
white vulgarians disgraced not only their nation, but the very name of men". ${ }^{60}$ Cambridge also refers to the Zong by informing us that slaves jumping off the ship or being thrown overboard are common practices on slave ships, either to escape slavery or to retrieve insurance money for the sick: "Some days later, having jettisoned the human cargo and taken on board fresh provisions, we hauled anchor and set sail for England". ${ }^{61}$ Following the transformation of a free African into a slave, also described by Equiano, is the acculturation to England. Olumide becomes Thomas, then David in Cambridge; Olaudah became Jacob, then Michael, and eventually Gustavus in Equiano's narrative. Phillips's narrative leans undeniably on Equiano's story; his use of pastiche enables the reader to relate to Equiano's time and experiences. After the adaptation to the Christian world, all slaves are content with their masters, according to Cambridge and Equiano. ${ }^{62}$ Adopting the Christian faith leads the slaves to perceive Africa as barbaric and makes them feel fortunate to have escaped that fate: "My uncivilized African demeanor began to fall from my person". ${ }^{63}$ Phillips continues to follow Equiano's tale; upon completion of his Christian education, Cambridge marries a white woman, Anna. At this point, Equiano's tale concludes. He spends

\footnotetext{
${ }^{60}$ Cambridge (138).

${ }^{61}$ Cambridge (139).

Note: the Zong was a slave ship that had insurance on "lost cargo" which lead to throwing sick and dead slaves overboard in order to claim the loss (Ian Baucom Specters of the Atlantic, 11).

${ }^{62}$ Cambridge (142-143).

${ }^{63}$ Cambridge (144).
} 
his life as a free man, considers himself an Englishman, and keeps working with the abolitionists. At this point, Equiano experiences his salvation insofar as he has been assimilated into British society.

When religious salvation concludes Equiano's tale, Phillips departs Equiano's path that he had needed in order to get published. Cambridge does not live his life as a free man. Instead of living happily ever after with his white wife and children in England, Cambridge's family dies. He is supposed to return to Africa and save "barbarian" souls there. From this point on, Phillips seems to have borrowed from Aphra Behn's Oroonoko. The classic narrative's use has shifted from Equiano to Behn: Cambridge's second life as a slave does not follow Equiano's happy ending, but adopts Oroonoko's fate. ${ }^{64}$ On the ship, Cambridge is being re-captured and confined to irons in the belly of the ship. The slave narrative starts all over: Middle Passage, life as a slave in the Caribbean colonies, finally marriage or relationship with an African woman (though Imoinda's and Christiania's characters differ). Both, Oroonoko and Cambridge, would have complied to life in slavery with their respective wives; however, without Imoinda or Christiania, they rebel against their masters and prefer being executed over living in slavery again.

${ }^{64}$ Aphra Behn. Oroonoko. 1688. 
While Phillips presents us with the slave owner's and then the slave's perspective, he weaves the official public opinion of the historical society of the West Indies into Cambridge's Part III. We read the "official" version of Mr. Brown's murder. It appears to be a historical newspaper article and is written in the third person voice of a journalist or court reporter. In part III Phillips turns Cambridge into a savage who had held Christiania in bondage and, after her escape, killed Mr. Brown. In Cambridge there are no winners and no survivors. It is a dark tale — in this respect like Oroonoko — that condemns everything about enslavement and concludes that nothing good can ever be born out of its misery. This chapter is only three pages long and thus a rather short account of events, one that tries to state so-called facts without explaining them.

Phillips presents several different facets of the events in the novel: female, male, slave, slave master or overseer, and finally the official version. Evelyn O'Callaghan concludes her essay with the claim that "Phillips has gone to great pains to establish the historical 'authenticity' of his fiction" as "each of his narratives is relatively consistent and suited to its presumed author". Phillips's use of pastiche may have served a different purpose than assumed by O'Callaghan as Phillips tried to deconstruct the authenticity of the classic with his pastiche. As a result, Phillips has employed the representative natures of the historic documents and combined their impressions to create a setting of the period and place of the story. O'Callaghan compares the texture of the novel to a web because the links between the different paternal narratives can be easily established: the parallels between the Middle Passage and sickness i.e. death 
become apparent. The similarities between Cambridge and the overseer Brown are apparent as they both lose the women in their lives, a child, and ultimately their lives. Cambridge takes the appropriation of the historical documents that Phillips used not only to the level of revisiting and reviving history, but challenges the reading of the original documents from a different view-point. The metafiction of this novel questions the "truth" of the original.

Phillips's ensuing novel Crossing the River is also a contemporary slave narrative, which tries again to grasp the whole misery of slavery, then attempts to accept it, and finally encourages closure. The two female protagonists, Martha and Joyce, are marginalized in this narrative, however, for different reasons. Martha, an African-American woman, remains enslaved to her fragmented life and loss of her family. Phillips himself tells us that the character of Martha is partly based on Sethe in Toni Morrison's Beloved. ${ }^{65}$ Both women survived the ordeal of slavery, but are traumatized for the rest of their lives by the losses they had to suffer as enslaved mothers. Joyce, as a white British subject, marginalizes herself by marrying a black GI in a white society. Phillips employs stylistic devices of postmodernism such as metafictional elements, a non-linear narration, and a chorus of voices. His multiple voices in Crossing the River include Nash's African father, Nash himself, an unnamed narrator relating Edward's voyage, Martha, an unnamed narrator relating Martha's tale when she cannot speak,

${ }^{65}$ Crisscrossing the River: An Interview with Caryl Phillips, in Ariel, Vol. 25, No. 4, October, 1994, pp. 91-99, eNotes. 26-Jul-2012 
James Hamilton, and finally, Joyce. Crossing the River conveys some hope of forgiveness and reconciliation towards the end of the novel.

The "river" is a metaphor for the Atlantic, and the father narrating the prologue is an allegory to Africa. We distinguish three protagonists in this threepart novel - Nash, Martha, and Travis - they are Africa's children. If we start reading with these ideas in mind, it is easier to relate to the novel as a slave narrative. Slavery as such was common in Africa before the British invasion, and selling slaves among the different tribes was not out of the ordinary. The difference with this "father" was selling his children across the river, i.e., to the white men across the ocean. The first-person voice is dominant, lyrical, at times even poetic. It relates the story of the slave trade and the subsequent life of slaves and their descendents over the course of 250 years by employing a multitude of voices. The italicized phrases are repeated throughout the novel by different voices. According to Phillips, there is no possible redemption for slavery. Nash's, Martha's, and Travis's African father's thoughts reveal:

There is no return. To a land trampled by the muddy boots of others. To a people encouraged to war among themselves. To a father consumed with guilt. You are beyond. Broken-off, like limbs from a tree. But not lost, for you carry within your bodies the seeds of new trees. Sinking your hopeful roots into difficult soil. And I, who spurned you, can blame only myself for my present misery. For two hundred and fifty year I have waited patiently for the wind to rise on the far bank of the river (Crossing the River 2). 
"Father Africa" uses the principle of Great Time with this description as introduced in chapter one. But even without return, there is hope. And Phillips represents this hope at the very end of his novel by introducing us to the character of Greer: None of Africa's children survived after "crossing the river". Greer, son of a black GI and a white English mother, had been given up for adoption and comes to find his biological mother as an adult. His return reveals him as the only survivor.

For the most part, Phillips follows the outline for the slave narrative in the first part of his novel; however, the end of "The Pagan Coast" does not reflect redemption. I would almost call this end revenge. Nash Williams, who is the protagonist of this part and largely the narrator of the first part, somewhat reverses the typical slave narrative. He experiences the common destiny of a slave: separation from his father, Middle Passage, slavery in America, education in bondage, adaptation to the Christian faith and finally freedom. Then, in 1820, his former master and emotional father sends him to Liberia to teach the natives civilization and Christianity. Nash crosses the Atlantic again, in the other direction this time, and as a freed slave. Most of "The Pagan Coast" is narrated in firstperson voice in the form of letters by Nash Williams.

According to Maroula Joannou's essay on Crossing the River, the language of the fictitious correspondence between Nash and Edward Williams "brings the exact vocabulary, cadences and phrasing of the genuine slave letter 
to mind, foregrounds the textuality of representation at the same time as it prompts the reader to ask whose history is known and by what means" ${ }^{\text {"66 }}$. Using the style of the slave letter takes us back in time and reminds us again that we are reading a postmodern slave narrative. Unfortunately, since his so-called mother (former mistress) intercepts Nash's letters, we only get to hear one side of the story. Nash realizes that Liberia is a place where "a colored person can enjoy his liberty, for there exists no prejudice of color and every man is free and equal". ${ }^{67}$

Nevertheless, Nash now acts like the white men did when they first came to Africa: he distinguishes himself from the natives. Since he has become a civilized Christian, he considers himself to rank above the natives: "Sadly, there is amongst some emigrants a tendency for lying about and doing nothing. True, it is very hot hereabouts, but after the industrious man achieves acclimatization, there is no excuse for not applying himself with unwearied dedication. Those who won't work and who get along by stealing are becoming something like the natives" ${ }^{68}$ Nash also expresses concern that "some emigrants hereabouts, having previously embraced religion and displayed the patience necessary to resist the temptation of the evil one, now dance to the discordant tune of

\footnotetext{
${ }^{66}$ Joannou. (2).

${ }^{67}$ Crossing the River (18).

${ }^{68}$ Crossing the River (18).
} 
drunkenness". ${ }^{69}$ Nash considers Edward, his former master, to be his father, but when the contact between them breaks off, Nash seems to regress and give in to that very same temptation he describes earlier. Just one year after his observations, he writes: "I am striving to do all the good I can amongst these natives, who form a most dominant majority. To this end I am even speaking a little of their crude dialect, which is very hard to learn". ${ }^{70}$ Instead of teaching the natives English, he learns their language. Furthermore, Nash starts to enslave people himself: "Yesterday I moved amongst the natives who labor about my land. They are good workers, although they require a stern and watchful supervision". ${ }^{71}$ Four years after this letter, the regression of the former slaves continues further. Nash writes "that old brother Taylor and sister Nancy have both lost all religion". ${ }^{72}$

By that time, Nash has been in Liberia for almost twenty years. In his life, he has been transformed from a free black man to a slave to a freed slave and now a master. He even calls himself a "white" man referring to his culture and language, neglecting his skin color altogether. "This white man [Nash] does talk true, for I think they have become much fond of me. Sadly, not all masters will

\footnotetext{
${ }^{69}$ Crossing the River (19).

${ }^{70}$ Crossing the River (23).

${ }^{71}$ Crossing the River (27).

${ }^{72}$ Crossing the River (27).
} 
converse in such a manner with these natives". ${ }^{73}$ For Nash, history repeats itself; only this time he is the master and his slaves come to love him just like he had came to love Edward. Nash even claims that the white man calls him Mr. Williams now. ${ }^{74}$ After twenty years of writing to his former master, Nash does not understand why he only received one letter in return. Nevertheless, he writes one more letter to inform Edward that he had married a native woman and demands that Edward send him supplies and money. "You will therefore send me something. Anything you may choose to send will be acceptable, and the sum of three hundred dollars, being of no consequence to a man of your wealth, would suffice" ${ }^{75}$ Nash is starting to love his new country, but urges his father - this time addressing him as master - to explain why he abandoned him: "Master, you took me into your house and instructed me in the ways of civilized man" and "Why have you forsaken me?"76

Edward comes to Africa in search of his former slave/son only to find that he died just hours ago and left him a letter. Nash Williams had come full circle and gone back to his roots. Nash had realized that Africans are by no means inferior to white Americans: He had three wives, learned the native African tongue of his new family, found his wives as loving and caring as an American-

\footnotetext{
${ }^{73}$ Crossing the River (32).

${ }^{74}$ Crossing the River (33).

${ }^{75}$ Crossing the River (38-39).

${ }^{76}$ Crossing the River (42).
} 
born woman, and suspended his Christian faith. He also did not consider America his home anymore: "We, the colored man, have been oppressed long enough. We need to contend for our rights, stand our ground, and feel the love of liberty that can never be found in your America". ${ }^{77}$ Nash Williams had been happy with his life as an African and wanted this way of life for his children, not the American way. The narrative reverses the conventional slave narrative by continuing the tale where it would typically have concluded. The return to Africa and its native customs is the redemption of this (fictional) narrative. When Edward visits Nash's final settlement, he cannot understand how Nash would choose that life over civilized life. Yet, the natives are happy, free, and they pity that "strange old white man". ${ }^{78}$ Nash Williams's slave narrative does not end as a free black man in a white world, but as a free black man in a black world in Africa: the way his life should have been in the first place, had he not been subjected to slavery.

Phillips's second part of the novel is titled "West" and narrates the tale of Martha Randolph, Nash's sister. Martha is an allegory to survivors of slavery and the Civil War. "West" is narrated in first-person voice when Martha speaks of her past and changes to third-person narrator when Martha's present and recent past are concerned. Phillips invokes an effective stream-of-consciousness in this part of his novel. Martha's life starts in slavery, and her family is lost to her through

\footnotetext{
${ }^{77}$ Crossing the River (61).

${ }^{78}$ Crossing the River (70).
} 
the common destiny of slaves: on the auction block. After the war, Martha is free and tries to move west to start a new life. Her new partner, however, gets killed by the white man again. Martha is doomed not to be happy; there is no redemption for her. This part of Crossing the River is only about twenty pages long; yet, it reflects Martha's feelings of abandonment quite effectively. They are the same sentiments her brother Nash had expressed toward Edward when he did not respond to him. Edward's desertion devastated Nash and he linked his situation to the Bible by exclaiming "Father, why have you forsaken me?"79 Between Martha's struggle to live without serving the white man and her hope to eventually re-connect with her daughter, she moves westward, falls sick, and feels abandoned all over again. ${ }^{80}$ "This episode harks back to well-known nineteenth-century slave narratives. Harriet Beecher Stowe's Uncle Tom's Cabin (1852) uses the sanctity of motherhood as its most powerful argument against slavery: Eliza, the slave, who runs away to the North to avoid being separated from her child". ${ }^{81}$ This second part of the novel ends on a hopeless note, with Martha dying alone and not even leaving her name. She simply disappears much like the many slaves who were lost on the Middle Passage, without a trace.

The Middle Passage dominates the third part of the novel, the actual "crossing the river," which is an eminent part of any slave narrative. It is

\footnotetext{
${ }^{79}$ Crossing the River (73).

${ }^{80}$ Crossing the River (75).

81 Maroula (3). This foot note serves as an explanation only.
} 
somewhat detached from Martha's and Nash's stories. Phillips bases his narration on John Newton's Journal of a Slave Trader and leans heavily on his ship's log book, though he uses a fictional name for the captain, James Hamilton. The journey takes place in 1752 and is narrated in first-person voice by the Captain Hamilton. The log tells us about the slave trade, the loading of the "cargo", followed by the crossing of the Atlantic. During the Middle Passage slaves learned what it meant to be a slave, what it meant to be subhuman. Captain Hamilton's notes reveal a calculating, cold, even cruel man. The captain will not hesitate to get rid of slaves who do not seem fit for their future task: "She came aboard at 9 a.m., brought with her 5 slaves, 2 fine boys, and 3 old women whom I instructed them to dispose of". ${ }^{82}$ This picture of Hamilton is juxtaposed by the inserted personal love letters to his fiancée, which almost reflect a caring, loving man. The combination of the log and the love letters makes the captain human, despite his cruelties towards the Africans. The end of this voyage poses the only link to the rest of the novel as Nash, Travis, and Martha are aboard the ship: "Approached by a quiet fellow. Bought two strong man-boys, and a proud girl. I believe my trade for this voyage has reached its conclusion". ${ }^{83}$

In his last chapter, Phillips's novel leaves the pattern of the traditional slave novel. Joyce's journal takes us into the twentieth century and presents us with a fragmented, non-linear narrative to conclude the story. Her entries are

\footnotetext{
${ }^{82}$ Crossing the River (113).

${ }^{83}$ Crossing the River (124).
} 
"mixed up" as they start in 1942, go back to 1939, jump back and forth, and finally end in 1963. Joyce's journal entries are narrated in her own first-person voice. Phillips employs stream-of-consciousness as a literary technique again. The Gl's name, Travis, is Martha's and Nash's brother in name only since the story is set 200 years later. Travis is an allegory to all descendents of slaves. Though "Somewhere in England" is not a happy tale, it is the only one to show survival and thus hope. Joyce's and Travis's son, Greer, wants to learn about his heritage and his roots. After he becomes of age, he contacts his biological mother and comes full circle. "Father" Africa finally hears the voice of one of his "children" and accepts the interracial sons and daughters of Africa, including their mother. "My Nash. My Martha. My Travis. My daughter. Joyce. All" and "Bought 2 strong man-boys, and a proud girl. But they arrived on the far bank of the river, loved". ${ }^{84}$ Someone had finally survived the Middle Passage unharmed, Greer. The fact that Joyce becomes part of that family, shows that the process of forgiving in slave history has finally begun.

Classic and postmodern slave narratives are reminders of the subhuman life of the slave and make us aware of the impossibility to redeem and redress the injustice of slavery; yet, there is a spark of hope for healing and forgiveness. To support this conclusion, Joannou describes Phillips's work's purpose as follows:

${ }^{84}$ Crossing the River (237). 
The contemporary black British novelist who has re-visioned the history of slavery the most extensively in his writing over a period of more than twenty years, as unfinished business in terms of its continuing impact on the sense of self and on relationships between black and white people in the modern world, is Caryl Phillips. Asked why any writer in the nineteennineties should still be writing about slavery, Phillips answered that slavery was 'the biggest of those shadows where the history of Europe meets the history of the Americas' (Phillips 1994, 26). Phillips has explored the history and cultural legacy of slavery in both his discursive writing and his fiction, including Higher Ground (1989), Cambridge (1991) and Crossing the River (1993), from a perspective that differs significantly from many black intellectuals in the United States.

With both novels, though, Phillips has made the history of slavery in America and in the Caribbean more accessible for his readers. His historiographic metafiction with its intense use of pastiche introduces us to the language and scenery of the lives of enslaved men, women and children during this era of total disregard for human rights. Phillips "shakes" the historical archive up and presents us with multiple perceptions of the slave's history. 


\section{CHAPTER 3}

\section{SHERLEY ANNE WILLIAMS'S DESSA ROSE AND}

\section{TONI MORRISON'S BELOVED}

Sherley Anne Williams's novel Dessa Rose was first published in 1986. Williams was born in 1944 in California and was an English professor at the University of California San Diego. She died of cancer in 1999 before she could complete the sequel to Dessa Rose.$^{85}$ Toni Morrison's Beloved was released in 1987. Morrison was born in 1931 in Ohio. She is an American novelist, editor and professor. In her work, she examines the lives of black characters who struggle with identity amidst racism and hostility. Morrison wants her prose to recreate the African Atlantic tradition of oral cultures, "to restore the language that black people spoke to its original power". ${ }^{86}$ According to Morrison, in the oral tradition the speaking of words, holding them on the tongue, playing with them, is as meaningful as the content of the word. One tragic outcome of slavery was the threat that posed the loss of the African oral tradition and the language of everyday life.

Toni Morrison's Beloved was inspired by a historical figure, who was Margaret Garner. She was a female slave in 1855 in Kentucky who had escaped from slavery and was about to be recaptured as a result of the Fugitive Slave Law. At that time she killed her baby in order to protect her from a life in

\footnotetext{
${ }^{85}$ from: http://ucsdnews.ucsd.edu/newsrel/general/cwilliams.htm

${ }^{86}$ from: http://academic.brooklyn.cuny.edu/english/melani/cs6/morrison.html\#overview
} 
servitude. Dessa Rose was inspired by two historical events and women, one of which she found in Angela Davis's Reflection on the Black Woman's Role in the Community of Slaves in which Davis details a pregnant woman's involvement in revolutionary rebellion to enslavement by armed resistance. Davis cites Herbert Aptheker's American Negro Slave Revolts for this incident in which Williams discovered the second story she resurrects from history, the white woman in North Carolina who is harboring runaway slaves. Dessa Rose is further engaged in intervening through its formal innovations in the discourses of power, authority, voice and race which framed the Confessions of Nat Turner, both the Gray (1831) and Styron (1967) version.

Both novels - Dessa Rose and Beloved - relate predominantly to AfricanAmerican history unlike Phillips's who focus more on the Atlantic-BritishCaribbean situation. Morrison's Beloved is as much about the nineteen-eighties as the eighteen-sixties and seventies. Both authors present us with model examples for the neo-slave narrative concentrating on the subject of enslaved mothers and their offspring as well as the African Atlantic heritage of slaves. ${ }^{87}$ In his work The Black Atlantic, Paul Gilroy refers specifically to Toni Morrison's Beloved and Sherley Ann Williams's Dessa Rose. He explains the purpose of these two neo-slave narratives in more detail. Both novels share the interest in history and social memory with all other neo-slave narratives that have been written to remember and not to forget slavery; however, they both focus on the

${ }^{87}$ See chapter one on Gates and Russell on African traditions and perceptions. 
issues of not only slavery, but what it meant to be a female slave. The Margaret Garner story conceptualizes the "confrontation between two opposed yet interdependent cultural and ideological systems and their attendant conceptions of reasons, history, property, and kinship. One is the dilute product of Africa while the other is an antinomian expression of western modernity. Their meeting ground is the system of plantation slavery". ${ }^{88}$ Furthermore, Gilroy explains the reasons why modern authors such as Phillips, Morrison and Williams explore slavery in fictional writing. He claims that they attempt to restage opposition of the European and American experiences of slavery as an economic necessity to the presumably primitive African slaves who had no culture or purpose other than to serve. According to Gilroy, an additional motivation for the neo-slave narrative's authors was the need to explain that the present racial conditions still stem from the above mentioned cultural differences and the assumptions that these conditions are still relevant.

The ensuing novels are "imaginative attempts to revisit the slave experience and sift it for resources with which to bolster contemporary political aspirations [...] from the West and its distinctive understandings of being, thinking, and thinking about thinking and being". ${ }^{89}$ Morrison supports the argument that racial slavery still influences modern society today, and that we can only attempt to do justice by exploring the past: "[...] modern life begins with

\footnotetext{
${ }^{88}$ Gilroy. The Black Atlantic (219).

${ }^{89}$ Gilroy. The Black Atlantic (220).
} 
slavery $[\ldots]{ }^{90}$ Morrison takes this argument even one step further by stating that "[s]lavery broke the world in half" and in order to heal, we need to remember and avoid repeating the same mistakes. The neo-slave narrative with its socialized historical remembrance helps to never forget the horrors of slavery and to act more responsibly for the future. Only if the past stays memorized in a nonromanticized form will we be able to move forward without racism. The rewritten history of the neo-slave narrative can provide everybody - white and black, male and female, upper and lower social class - with the necessary insight to move forward in the right direction. With this thought in mind, there is hope and reason why the neo-slave narrative remains a relevant and important part of American literature.

Responding to the rise of the neo-slave narrative in the nineteenseventies, Deborah E. McDowell asks, "Why the compulsion to repeat the massive story of slavery in the contemporary Afro-American novel, especially so long after the empirical event itself? [...] Is the retelling meant to attempt the impossible 'to get it right,' to 'set the record straight?' ". ${ }^{91}$ McDowell quotes Sherley Anne Williams, who "suggests that history's lie can be corrected and its omissions restored". ${ }^{92}$ That perception of correction may be doubtful; however, not questionable is the fact that the novel is credible and thus another witness to

\footnotetext{
${ }^{90}$ Gilroy. The Black Atlantic. (221).

${ }^{91}$ Deborah E. McDowell: Slavery and the Literary Imagination (144).

${ }^{92}$ McDowell (145).
} 
the era of slavery. As such it helps the main purpose of the neo-slave narrative to find a way to comprehend history, try to forgive and possibly draw conclusions for the future. Dessa Rose touches an additional aspect of slavery than violation of basic human rights. It also sparks the interest in the personal drama and injustice that the institution of slavery had caused, but the novel specifically focuses on the particular burden for enslaved women and their children. We have already seen this approach in classic slave narratives such as Harriet Jacobs's Incidents in the Life of a Slave Girl, and it does not come as a surprise that the modern sibling would pick up on this particular issue as well. In addition to this thematic nuance, Williams does not rely on authenticating sources such as pastiche as much as Phillips. She refrains from employing historical texts and instead concentrates on discourse as a means to make her story. She uses "speakerly text", especially in the first part of her novel in which she leans on Nat Turner's Confessions respectively Thomas Gray. ${ }^{93}$

As a postmodern novel, Dessa Rose exemplifies many of the features of historiographic metafiction as described by Linda Hutcheon insomuch as "postmodern writing of both history and literature has taught us that both history and fiction are discourses, that both constitute systems of signification by which we make sense of the past". ${ }^{94}$ And making sense of the past is - as emphasized throughout this thesis - the first step to understand history. Nobody doubts

\footnotetext{
${ }^{93}$ Ref. Henry Louis Gates. The Signifying Monkey.

${ }^{94}$ Hutcheon (89).
} 
historical facts, but it is important to find out what their impact was and why. Linda Hutcheon calls this reasoning about history a "shift from validation to signification". ${ }^{95}$ Historical metafiction then helps us to select and to position historical events and characters in order to understand their significance and possible impact on the future much more than simply to try to prove a fact.

Williams's claim to correct (as in set right) history with her story may not be possible, but her approach of writing history anew is certainly following Oscar Wilde's advice: "The one duty we owe to history is to re-write it." ${ }^{.96}$ In her introductory note, Williams explains that her novel is based on two historical sources as well as two corresponding historical female characters. The first source talks about a pregnant, enslaved woman who remained anonymous and became Dessa Rose in Williams's fiction. The second source reveals a farm owner who provided shelter for runaway slaves in 1830 in North Carolina and who became Rufel in Dessa Rose. Williams also admits, that her narrative was the answer to William Styron's 1967 novel about Nat Turner's so-called confessions. Styron (as a white male author) assumed the voice of a black man, while Williams (as an African-American female author) slipped into the role of a white woman (Rufel). Her fiction combines the two historical figures mentioned above. The first person, the pregnant enslaved woman, supported an uprising of a slave coffle in 1829 and was convicted to be hanged. Her sentence was

\footnotetext{
${ }^{95}$ Hutcheon (96).

${ }^{96}$ Oscar Wilde. The Critic as Artist (14).
} 
postponed until after the birth of her baby for the economical reason of not discarding an additional slave. The second person, the wife of a farm owner in North Carolina, protected escaped slaves in 1830 from prosecution and recapture. Williams's novel was born by seeking an answer to the question of what might have happened if these two women had met. In order to find a possible solution, Williams rewrote history. While Williams admits to have invented the settings and characters of her novel, she based them on facts and thus, she claims, makes them "as true as if I myself had lived it". ${ }^{97}$

Williams does not offer a happy or unhappy ending of Dessa's destiny, but she gets her readers thinking and involves them in the past and the issues of slavery from the slaves' perception. This thinking-understanding process is the essential task of the neo-slave narrative more so than the intended solution reconciliation - would be. Williams merely insinuates that there may be an eventual chance for forgiveness, trust and friendship between Rufel and Dessa, who serve as representatives for their respective race and class. The conclusion of Dessa Rose suggests this notion of beginning reconciliation when Dessa Rose and Ruth start using their real names as a sign of mutual respect: "We couldn't hug each other, not on the streets, not in Arcopolis, not even after dark; we both has sense enough to know that. The town could even bar us from laughing; but that night we walked the boardwalk together and we didn't hide our grins". ${ }^{98}$

\footnotetext{
${ }^{97}$ Dessa Rose (6).

${ }^{98}$ Dessa Rose (233).
} 
Nevertheless, referring to Dessa Rose by name and not just thinking of her as a "darky" shows the process of Ruth's changing perception of Dessa Rose as a human, even equal being. How could this shift in Ruth's or Dessa's opinions of each other (both fictional characters) correct history? I will have to agree with McDowell that it cannot. "This is the difficult and precarious balance that contemporary novels about slavery must strike - that between the public record and private memory". ${ }^{99}$ But while history cannot be corrected, it can be understood and serve as a source for a healing process. Williams tries to imply a change of attitude between her characters by letting them have conversations instead of just narrating their story. Through the use of their language, the characters seem to become real. Her attempt is thus different from Phillips's, who employs multiple voices as well but does not have them converse with each other. Williams's novel exemplifies how language and discourse have an impact on the presentation of events in a story.

In his essay Discourse in the Novel, Mikhail Bakhtin discusses how both language and discourse operate in novels. He claims that socially and historically specific forms of language add positive qualities to fiction. The use of several languages, however, cannot be confused with different dialects. The dialects are a separate instrument than the languages used in original slave narratives. The languages operated mainly on one level: the former slave re-tells his past adventures, dialogue is inabundant. Mikhail Bakhtin uses the expression

\footnotetext{
${ }^{99}$ McDowell (156).
} 
heteroglossia to describe the coexistence of distinct varieties within a single linguistic code. Though the characters do speak the same language - in our case English - they may use different dialects which mirror their social status, age group, or ethnicity. According to Bakhtin, any language represents a distinct view and words do not exist until spoken: "The [...] incorporating and organizing heteroglossia in the novel [...] is verbally and semantically autonomous; each character's speech possesses its own belief system". ${ }^{100}$ While overly displayed polyphony would discredit an original slave narrative (by suggesting that the author was incapable of writing in platform English), it supports the reader's ability to differentiate between the characters in the neo-slave narrative. In Williams's Dessa Rose, for example, each character owns his or her specific language. By following the discourse, the reader may figure who is speaking without Williams indicating who is talking. Williams's novel is a meta-narrative and employs many voices to tell all its stories. The following pages show how Dessa Rose is exemplary of polyphony and its effects.

The prologue is Dessa's own narration of her satisfying, fulfilling relationship with Kaine. This part is printed in italics, which Williams uses to indicate that she is referring to Dessa's past. Dessa and Kaine speak their own language in their dialogue and relate the love and passion between them. Dessa tells her man upon his return from work "Our greens going get cold". ${ }^{101}$ Kaine,

\footnotetext{
${ }^{100}$ Bakhtin (315).

${ }^{101}$ Dessa Rose (13).
} 
though he must be tired and hungry after a long day of laboring in the sugar cane fields, ignores the meal, embraces Dessa, and answers "But we ain't". ${ }^{102}$ His answer implies that the feelings and emotions of the couple are more important than any material reference such as food. This short discourse between Dessa and Kaine emphasizes their status as humans, which is not the general perception of enslaved workers by their masters. The prologue introduces Dessa and Kaine as an emotional and caring couple. The picture we get from that introduction makes it hard to believe that Kaine, or Dessa, would cold-bloodedly attack their masters without reason. The fictional conversation Williams uses here is the tool that leaves us with her intended perception of Dessa and Kaine as loving and hard working instead of two slaves with their only purpose in life to do hard labor. Following the prologue, Williams's novel consists of three main parts and concludes in an epilogue.

In the first part, "The Darky", we distinguish three voices. The first voice belongs to the narrator, Nehemiah, who speaks through his diary of recorded interviews with Dessa Rose. The diary is written in platform English. We know immediately that the recordings are those of an educated white man, contemptuous of Dessa: "The darky demanded a bath this morning, which Hughes foolishly allowed her". ${ }^{103}$ Nehemiah does not refer to Dessa by her name

${ }^{102}$ Dessa Rose (13).

${ }^{103}$ Dessa Rose (32). 
but calls her "the darky". Both white men, Nehemiah and Hughes, seem surprised at Dessa's request to clean up as they do not expect her to care about her health or body. A second voice is Dessa's own which relates her memories and, as in the prologue, is printed in italics when referring to the past. During the interview, Dessa barely speaks to Nehemiah. To frame and connect the diary and Dessa's thoughts to the present time of the narrative, Williams utilizes a third person omniscient narrator. Within this present tense narration, we find multiple voices such as Dessa's own in vernacular language: "I kill white mens cause the same reason Masa kill Kaine, Cause I can". ${ }^{104}$ Also using a locally colored voice, we can identify the overseer, Hughes: "How else kin a nigger in her condition keep happy, cept through singing and loud noise?"105 Hughes discourse, even as a monologue, qualifies Dessa as a lower being while Hughes himself is clearly also not a member of the upper class (his own dialect indicates his social class). The discourse of the characters displaying their own specific language makes the scenes come to life. Williams employs what Robert Stepto would call the "pregeneric myth" which existed before the written word such as singing or story telling. ${ }^{106}$

The second book, "The Wench", keeps the omniscient third person narrator and the first person voice of Dessa Rose printed in italics, a technique

\footnotetext{
${ }^{104}$ Dessa Rose (20).

${ }^{105}$ Dessa Rose (29).

106 Stepto (Preface)
} 
used to reveal more and more of Dessa's past to us. There is also a conversation between Dessa and Ada, a servant on Rufel's farm. Her language indicates her being a member of low social class even if we do not have the description of her being a "tall brown-skinned woman". ${ }^{107}$ Any discourse by Ada indicates a member of the working class talking: " 'Pain going to get worse before it get better - that is, if you aint dried up. It's a mercy if you not, way you been carrying on.' She laughed. 'Attacking white folks and scaping all crost the country in the dead of night.' ' . ${ }^{108}$ In the classic slave narrative Henry Louis Gates would call this vernacular language "the talking book". In the neo-slave narrative this dialogue is the "speakerly text". ${ }^{109}$

Since Dessa has escaped her imprisonment, we do not read Nehemiah's diary anymore. Instead, Rufel enters the narrative, and her conversations with the escaped slaves hiding on her farm add dialogue to the novel, some of which is written out in dialect. "The Wench" is more about agency and identity than use of language. It is about Ruth (Rufel) learning the slaves' names, including her old mammy whom she claimed to love, yet whose name she did not know, much less if she had had children of her own. Williams uses Ruth to show the progress of turning property into human beings. The doubts Dessa can raise by asking Rufel about Mammy make Rufel think about whether Mammy had loved her or

\footnotetext{
${ }^{107}$ Dessa Rose (89).

${ }^{108}$ Dessa Rose (89).

${ }^{109}$ Henry L. Gates. The Signifying Monkey.
} 
merely complied with the expectations the family had of her. The dialogue Dessa and Rufel have about Mammy, makes the characters plausible and relate the growing desperation Rufel feels when she finally realizes that Mammy may just have been another house slave. Dessa challenges Rufel: “[...] You don't even not know 'mammy's name. Mammy have a name, have children", then Rufel denies Dessa's notion and responds unbelievingly that "She [Mammy] just had me! I was like her child". ${ }^{110}$ The discourse about Mammy's actual role and her imagined role in Rufel's mind tells us all we need to know about the relationship between Rufel and Mammy. The conversation takes the role of the narration. Without pointing out who is speaking, the form of the language leads us to know who is talking. It does not even matter that Dessa and Rufel refer to two different Mammys because the role of a mammy was always the same; however, the dialogue gets Rufel to think. Williams lets the fictional discourse between her characters carry her novel. The use of polyphony in this way lets the fiction appear credible and real, simply because this kind of conversation could have taken place in a similar way. Through the discourse Dessa gains some agency, especially since she is speaking to a white woman expressing her own thoughts and beliefs. This development of giving voice to Dessa continues in the third part of the novel, "The Negresse".

Dessa becomes the main narrator in this last part. She tells us about the fugitives' staying at the farm and their traveling with Rufel from Dessa's

\footnotetext{
${ }^{110}$ Dessa Rose (119).
} 
perception. The only vernacular we find here is presented in dialogue. Nehemiah re-appears as the never-relenting slave hunter; however, his voice becomes less important. He falls apart, and Williams underlines this fact by altering his name from Nehemiah to Nemi. Nemi loses agency and fades out of the novel. Dessa's voice, on the other hand, gains agency in the novel's last part. Williams's use of Dessa as the main narrator contrasts the beginning of the novel, where Dessa had no voice. Dessa's progress is not only illustrated by her first person voice, but also by the fact that it has become much more sophisticated, appearing in only slightly tainted standard English.

Dessa Rose is predominantly narrated in third person voice and thus represents mostly Dessa's point of view, which is somewhat reflective of Williams's. Bakhtin describes this facet of the narrator in relation to the author's as follows: "Behind the narrator's story we read a second story, the author's story; he is the one who tells us how the narrator tells stories, and also tells us about the narrator himself'. ${ }^{111}$ Bakhtin's narrator level is a belief system full of objects and feelings while his author level tells the means of the story in a refracted way. The neo-slave narrative operates in a similar fashion, according to Stepto, the neo-slave narrative "forwards the historical consciousness of the tradition's forms, and helps define those kinds of narratives which will also advance the literature in their turn". ${ }^{112}$ Though Stepto refers to Zora Neale

\footnotetext{
${ }^{111}$ Bakhtin (314).

112 Stepto (166).
} 
Hurston's Their Eyes Were Watching God, his statement is valid for Dessa Rose as well. Both novels work through dialogue and both heroines, Janie and Dessa, gain agency through their conversations and use of vernacular language that turns more and more into platform English.

In Dessa Rose Nehemiah presents Dessa's low social status by suppressing her voice. He is the literary component of the discourse while Dessa is presented as the opposite. Nehemiah is not really telling Dessa's story. He is reconstructing it. Williams wrote her novel as a response to William Styron's Nat Turner, she is signifying on Styron and Gray; however, neither Styron nor Gray told Nat Turner's story. They interpreted Turner's confession and tried to reconstruct history from their points of view. This tactic does not necessarily make the tale less plausible, but it represents a facet of history. ${ }^{113}$ As for Dessa Rose, we cannot forget that Nehemiah and Dessa are fictional characters and that Williams demonstrates with Dessa's voice that literacy is not the only way to relate history. She illustrates in Dessa that African-American slaves passed their stories on by orality such as singing and talking in vernacular language. Robert Stepto calls this oral telling "the historical consciousness of the tradition's narrative forms". ${ }^{114}$ By presenting a semi-literate character such as Dessa Rose, Williams promotes Dessa's orality beyond the representation by Nehemiah. She

\footnotetext{
$\overline{113}$ Styron's Nat Turner was highly controversial being released during the Black Power movement and portraying the perspective of a slave by a white author.

114 (Stepto 166).
} 
presents us with the speaking - not writing - black voice of Dessa. Dessa shows the struggle between literary expression versus emancipatory orality which fits the earlier mentioned African way of passing on history. However, Williams's representation is an imaginary reconstruction that could have happened this way yet is not a recording of history.

Williams's attempt to reconcile history and present lives partly in the effort to make the two heroines of her story understand each other: the white woman and the black woman try to get under each other's skins. Dessa Rose has to correct her opinion of the white woman and Rufel has to revise hers about the black woman. Williams presents a multitude of facets of both women - one of which is extremely important - Williams shows the human side of both women. She illustrates that Rufel's mammy, whom Rufel had adored, may not have acted out of love but simply due to the fact that she was Rufel's slave and as such was condemned to obedience. Dessa, on the other hand, had to realize that Rufel was not simply any white woman, but acted out of pure kindness by helping her save her baby. It is this call for understanding each other that has been used before in the classic slave narrative. When Mary Prince traveled to England she used this opportunity to make the English understand what slavery in the British colonies was like, she used the same approach. In her narrative she explains "I have been a slave myself - and I know what slaves feel - I can tell by myself what other slaves feel, and by what they have told me. The man that says slaves 
be quite happy in slavery - that they don't want to be free - that man is either ignorant or a lying person". ${ }^{115}$ That appeal to humanity and the effort to be heard were Prince's attempts to gain support for the abolition of slavery in the British colonies. Dessa is trying to make Rufel understand and Rufel is listening to Dessa. This common effort of comprehending each other and each other's situation is the key to forgiveness. Williams shows us a lesson learned by having Rufel actually hear and listen to other voices such as Dessa's.

While Williams signifies on Styron's novel, she also adds a momentum that is absent in Styron's Nat Turner as well as in historical descriptions of accounts of slave revolts: the acknowledgment of women who participated in any uprising. If a female is mentioned, she typically remains nameless. Angela Davis informs us about the original source of the slave coffle's uprising which Williams uses as basis for Dessa's character. She writes that "of the six leaders sentenced to death, one was a woman" who was "first permitted for reasons of economy, to give birth to her child" before being hanged publicly. ${ }^{116}$ Davis feels that this particular revision of history is important because it changes the image of the enslaved female who gave in to slavery without a fight. By giving the unnamed woman of the coffle uprising a way out of slavery and a name, Williams facilitated the necessity of comprehending the other history, the one that is not

\footnotetext{
${ }^{115}$ Mary Prince. The History of Mary Prince (288).

${ }^{116}$ Angela Davis. Reflections on the Black Woman's Role in the Community of Slaves. Black Scholar 3.4 (1971). 2-15.
} 
mentioned in Nat Turner's confessions or any other historical event. Williams's construction of Dessa and reconstruction of history describes a facet that has actually been neglected and never been told. In inventing Dessa, Williams gives the unmentioned women of slavery revolts a name, a face, and more importantly, a voice. By letting Dessa get away and not be executed, Williams gives her fictional character the opportunity to tell her story and her role in the uprising.

By choosing to let Dessa survive, Williams attempts to recall the remembrance of women rebels of slavery who are rarely mentioned in historical records and if so, the records are about their deaths. ${ }^{117}$ She shows what sacrifices enslaved women had to make in order to gain freedom for themselves and their children. Williams's reconstruction and rewriting of history fills a gap for which we have no historical reports, even though we know that female rebels existed. As Linda Hutcheon states, "historiographic metafiction attempts to demarginalize the literary through the confrontation with the historical". ${ }^{118}$ She further writes that "historiographic metafiction suggests that truth and falsity may indeed not be the right terms in which to discuss fiction [...] but that there is rarely falseness per se, just others' truths". ${ }^{119}$ The main purpose of rewriting and representing history wrapped in fiction is to make it as accessible and plausible as possible. By presenting a multitude of facets of history - or many truths - the

\footnotetext{
${ }^{117}$ ref. Hartman, Davis, Aptheker

${ }^{118}$ Hutcheon (108).

${ }^{119}$ Hutcheon (109).
} 
big picture becomes more coherent. Stepto claims in his preface, that "the historian of Afro-American literature must attempt to define and discuss how the myth both assumes and does not assume the properties of genre - notably, in this context, the properties of autobiography, fiction, and, to a lesser degree, historiography". ${ }^{120}$ As such, the neo-slave narrative is the response to the classic slave narrative. Dessa Rose is more on the historiographic side of the responses, and it serves its purpose well.

Similar to Dessa Rose, Beloved is concerned with the enslaved woman's life and that of her children. Most of Beloved revolves around the effects of Sethe having killed her baby girl. The murder haunts Sethe as the baby comes back, first appearing as a ghost and then materializing as the nineteen-year-old Beloved. Thematically, Morrison emphasizes the production of new slaves by their enslaved mothers and the sometimes resulting preference of the mother to rather have a dead than an enslaved daughter. While Phillips and Williams built on classic slave narratives respectively historical events and wrap them in fiction, Toni Morrison's novel Beloved weaves history and memory into fiction. However, Morrison also feeds on the classic slave narrative and history insomuch as she leans on Harriet Jacobs's Incidents in the Life of a Slave Girl and additionally incorporates the historical record about Margaret Garner. In Morrison's novel, Margaret Garner became Sethe and her baby turned into Beloved respectively Beloved's ghost in Ohio in 1873. Sethe keeps Beloved from a future life in

\footnotetext{
${ }^{120}$ Stepto (ix).
} 
slavery by killing her, while she shelters her free-born daughter Denver from the past by isolating her from the world. Sethe remembers the nightmare of Beloved's death and its consequences for herself and Denver. When the past in the form and shape of Beloved's ghost seems to first envelope and then drown Sethe, Denver leaves the cocoon her mother has built for her. She helps Sethe tackle the past in order to heal and master the future. Real memory, imagination, and dreams are mixed into fiction in Morrison's novel.

Marilyn Sanders Mobley suggests "that the intertextual relationship between Beloved and the slave narrative - the genre that began the AfricanAmerican literary tradition in prose - offers significant interpretative possibilities for entering the hermeneutic circle of this novel". ${ }^{121}$ She further argues "that Morrison uses the trope of memory to revise the genre of the slave narrative and thereby to make the slave experience it inscribes more accessible to contemporary readers". ${ }^{122}$ This intention is the purpose of the neo-slave narrative as discussed earlier in this thesis. For the most part Beloved employs the features of a slave narrative by describing life in slavery; however, the novel also explains some of the psychological effects of slavery and how the past and the present are intrinsically connected. The invitation to retrospection and making

\footnotetext{
${ }^{121}$ Marilyn Sanders Mobley. A Different Remembering: Memory, History and Meaning in Toni Morrison's Beloved (69).

${ }^{122}$ Mobley (69).
} 
sense is caught in the many dialogues, imagination and wandering through time, going back between the era of slavery and the time after the abolition thereof.

Marilyn Sanders Mobley states is her essay, that "Morrison's purpose is not to convince white readers of the slave's humanity" which was one of the purposes of the classic slave narrative, "but to address black readers by inviting [them] to return to the very part of [their] past that many have repressed, forgotten or ignored". ${ }^{123}$ At the same time, Morrison does introduce bits and pieces of the classic slave narrative into her novel by telling Paul D's fragmentary accounts of his past and showing us how powerless the slaves were to the oppression by their masters. One of the most shocking incidents of this kind is the stealing of Sethe's milk while her husband was watching helplessly because he could not intervene for fear of his own life. Paul D's memory of this atrocity triggers Sethe's memory and has her travel back in time to a place she wants to repress and forget. Even her mistress was unable to help, and her new master punished her severely for telling his wife about the incident. These kinds of memories remind of the historical memories of Harriet Jacobs and Mary Prince when they relate their unspeakable experiences as enslaved women. Though Sethe's and Paul's memories are fictional, they represent collective memory - as does Morrison's novel - and they serve the same purpose as the real memories of the classic slave narrative. They tell of abuse of slaves.

\footnotetext{
${ }^{123}$ Mobley (75).
} 
The introduction of Morrison's novel reminds us of all the victims of slavery, "sixty million and more". According to Tim Ryan's Calls and Responses "Morrison flirts with the horrific possibility that slavery might indeed have had a profound effect upon human identity". ${ }^{124}$ She fully compares American slavery to the Nazi Holocaust concurring with Paul Gilroy who considers "exchanges between blacks and Jews [are] important for the future of black Atlantic politics as well as for its history". ${ }^{125}$ In her novel's dedication Morrison cites the number of victims of slavery to be tenfold of the Holocaust murders. The slave ship and the survivors' destinies that Morrison describes as collective memory, serve as a comparison to the concentration camps of Nazi-Germany. The psychological chains of slavery and the Holocaust haunt the survivors and their descendents to the present day. Morrison employs a ghost as the haunting device and insomuch drifts off to fantasy and fiction more than Williams and Phillips.

Beloved's ghost refers to the slave ship experience in one of her monologues. Morrison uses Beloved's ghost to relate memories of the very beginning of slavery, such as the crossing of the Atlantic. Though Toni Morrison does not point out that the following scene is set on a slaver, it becomes clear by the use of language and way of writing. NourbeSe Philip's Zong employs the same tool to invoke the feeling of fragmentization and interruption. ${ }^{126}$ Morrison

\footnotetext{
${ }^{124}$ Tim Ryan. Calls and Responses (145).

${ }^{125}$ Gilroy. The Black Atlantic (xi).

${ }^{126}$ NourbeSe Philip. Zong.
} 
does not use punctuation. Her depictions are fragmented and the pictures she paints are frightening. Morrison's use of language mirrors the uproar and confusion of the slaves who were captured, thrown in the slave hold in the belly of the ship, and given no explanation as to what was going to happen to them. To demonstrate the fragmentation and the lack of explanations, Morrison uses blanks in lieu of punctuation. To add to the confusion, she calls the white tormentors "the men without skin" because most captivated Africans had never seen a man with white skin, a colorless man. ${ }^{127}$ The scene tells of the desire to rather die than be subjected to slavery:

we are all trying to leave our bodies behind the man on my face has done it it is hard to make yourself die forever you sleep short and then return in the beginning we could vomit now we do not now we cannot (Morrison 210).

Beloved's ghost describes the conditions in the slave hold of the ship without room to stand up, always in a crouched position with a dead man lying on top of her. There is nobody to get him off of her or take care of the living, human cargo awaiting delivery, death, or being thrown overboard. Morrison blends collective memory of slave history with personal memory of Beloved as a baby. Towards the end of this monologue, Beloved tells us about the experience of floating in the water, of being thrown away, and merges these two forms of

${ }^{127}$ Beloved (210) 
remembrance: the one of the drowned slaves of the slave ships and the one of her own death by her mother's hand.

I come out of blue water after the bottoms of my feet swim away
from me I come up I need to find a place to be the air is
heavy I am not dead I am not there is a house [...]
Sethe's the face that left me Sethe sees me see her and I see
the smile her smiling face is the place for me it is the face I
lost
(Morrison 213).

This same need and desire is what Sethe feels through Beloved and it makes Sethe feel she that she herself is drowning. It is where she loses touch with reality and seems to give in to the past instead of trying to move forward. The moving back and forth between the past and the present in conjunction with the dead coming back as ghosts reminds again of the African concept of Great Time where past, present, and future melt into one and interact.

Morrison keeps weaving the memory and imagination into reality. In another monologue, Beloved relates a dialogue between herself and Sethe as she imagines it and again combines collective history with her own personal one:

Tell me the truth. Didn't you come from the other side?

Yes, I was on the other side.

You came back because of me?

Yes.

You rememory me?

Yes. I remember you. 
You never forgot me?

Your face is mine.

Do you forgive me? Will you stay? You safe here now. (Morrison 215) Madhu Dubey states that Morrison opens "a cluster of generic possibilities" through Beloved's literal return from the dead. ${ }^{128}$ One of these challenges is that Morrison breaks away from the traditional expectations for an American novel. Beloved's "miraculous resurrection" disassociates Beloved from the Western way of thinking and associates it to imagined African roots. The imaginary conversation between Beloved and Sethe shows the connections between the past and the present and intensifies the bond between the dead (Beloved) and the living (Sethe). Dubey calls Beloved's return from the dead a complete "join" that makes it possible "to undo the history of slavery". ${ }^{129}$ According to Dubey, Morrison believes in magic and declares magic to be a part of her heritage and of African heritage in general. He further states that Beloved calls for a literal and a symbolic reading of the supernatural. With this point of view in mind, Morrison's novel closes a gap that the nineteenth century slave narrative left open. Similar to the classic narrative, Beloved unveils the atrocities of slavery, "but the novel refuses the assumption, central to the slave narratives, that print literacy is the most effective means of demonstrating the humanity of the slave". ${ }^{130}$ Morrison

\footnotetext{
${ }^{128}$ Madhu Dubey. The Politics of Genre in "Beloved".

${ }^{129}$ Dubey (193).

${ }^{130}$ Dubey (195).
} 
relies on magic to show the humanity of the slaves, the way they were singing and dancing and turning into someone else, for example during their meetings with Baby Suggs in the Clearing. ${ }^{131}$ The ghosts and myths are still with the slaves, their African heritage which traveled the Middle Passage with their ancestors. $^{132}$

Morrison invests effort to emphasize oral and performative heritage rather than engaging in literary and linguistic modes of expression only. In other words, Beloved does not rely on dialog and monologue using specific language assigned to specific persons as much as Dessa Rose. The sessions with Baby Suggs and the embracing of Sethe when she finally turns to her former friends and neighbors to escape her solitude and nightmares, involve rituals and singing. ${ }^{133}$ Beloved leaves the house with Sethe to face the group of women whom Denver had asked for support. The scene reminds of an exorcism ritual. Other than in the past, the group encourages Sethe and their effort is transformative. Sethe finally attempts to escape her past to move on. Angela Davis states that spirituals and work songs originating in the slave era, were aspirations for freedom. ${ }^{134}$ They were full of hope. Different musical expressions such as blues mirror the disappointment after the emancipation when it became

\footnotetext{
${ }^{131}$ Beloved. (88).

${ }^{132}$ Ref. Russell's Legba's Crossing

${ }^{133}$ Beloved. (261).

${ }^{134}$ Angela Davis. Blues Legacies and Black Feminism. (4).
} 
clear that not much had changed for the freed slaves. Beloved seems to be built on this disappointment as it shows how Sethe is unable to shake off the chains of slavery. Her memory captures her in a way that keeps her from overcoming Beloved's murder. Only when the joining of the past and the present finally happens, is Sethe able to overcome her slave history and try to live her life in freedom. This acknowledgment is the essence of the neo-slave narrative that we find in every one of them: history can never be changed, but it can be dealt with in order to be able to live with it. The Middle Passage or the murder of Beloved cannot be undone, but they can be overcome. Beloved registers the collective horrors of the history of slavery and the vast disappointment of empty promises after the emancipation and even the Civil Rights movement, but it does provide a glimpse of hope in its conclusion. 


\section{CHAPTER 4}

\section{THE NEO-SLAVE NARRATIVE BEARING WITNESS}

The slave narrative's general purpose was the testimony to the cruelty of chattel slavery. The emphasis was on the notion of truth from the slave's point of view in order to appeal to the humanity of the white world and to put pressure on the slave-holding nations or states to abolish slavery. The stories were told by survivors of slavery who told the truth as witnessed in their experience. Their testimony relied on truth more than anything, and if we eliminate truth as too specific, there is no testimony. Hence the authors of the classic slave narrative were preoccupied with the burden of proof, truth and authenticity. On the other hand, they could not afford to offend the white majority as they needed them to publish their novels and to support abolition. After the emancipation, the writers of the neo-slave narrative did not have to worry about truth or testimony. They could present many truths from different points of view. They acted and keep doing so in order to bear witness to a time which most of us today refer to as history. The neo-slave narrative is not trying to correct history, but it is aiming to understand and analyze history with the goal to overcome the consequences we still suffer today: racism in a still racialized society.

By historicizing fiction the neo-slave narrative rewrites history and keeps slavery alive. Since the goal of the postmodern novels is to seek reconciliation, it is not imperative to provide testimony but to inform and explore. Caryl Phillips, Sherley Anne Williams and Toni Morrison wrote their fiction using similar yet different ways of informing us. They all wrapped history in fiction to capture our 
interest. Phillips relied on original sources and weaved them via pastiche into his plots, while Williams combined two historical sources and employed polyphony and dialogism as her major tools. Morrison worked with the same major literary devices as Williams but added magic, memory and African heritage to create her novel. All four of the neo-slave narratives ignite our fantasy and take us on a journey to re-visit the past. As Linda Hutcheon defines the postmodern historical novel not to present falseness but others' truths, we cannot discuss historical metafiction such as the neo-slave narrative in terms of truth and falsity, but in terms of a confrontation of history. ${ }^{135}$ According to Hutcheon, historical novels are structured, coherent and incorporate social as well as political history. Seen in this context, historiographic metafiction attempts to demarginalize history formally and thematically by confronting and analyzing it, something the classic slave narrative could not achieve as it could only speak of what had happened. It could only relate the particular facts of the past. The neo-slave narrative, on the other hand, is poetry and as such can explore possibilities as of what might have happened. This freedom from facts enabled the neo-slave narrative's authors to choose to alter events: Sherley Anne Williams and Toni Morrison did so by letting their version of the female rebel survive and move on, and Caryl Phillips followed that example by having Nash return to Africa and revert to his African beliefs.

The neo-slave narrative has far more elastic boundaries than its classic precursor. History and fiction blend without lacking plausibility. The novels

\footnotetext{
${ }^{135}$ Hutcheon. (107-109).
} 
discussed in this thesis keep the historical context of slavery intact but at the same time they allow for re-positioning and re-experiencing it. Historiographic metafiction bears witness to the institution of African Atlantic slavery and will have to continue to do so until racism as its last witness has been eliminated from our society. 


\section{REFERENCES}

Aptheker, Herbert. American Negro Slave Revolts. 6th ed. N.p.: International, 1993. Google Book Search. Web. 10 Nov. 2012.

Bakhtin, M[ikhail] M. "Discourse in the Novel." The Dialogic Imagination: Four Essays. Ed. Michael Holquist. Trans. Caryl Emerson and Michael Holquist. U of Texas P Slavic Studies 1. 1975 (Russian). Austin: U of Texas P, 1981. 259-422. Print.

Beecher Stowe, Harriet. Uncle Tom's Cabin. 1852. Dover Thrift ed. 2005. Print.

Behn, Aphra. Oroonoko. 1688. New York: Penguin, 2003. Print.

Bell, Bernard W. The Afro-American Novel and its Tradition. $\mathrm{U}$ of Massachusetts $\mathrm{P}, 1987$. Print.

Carmichael, Mrs. Domestic Manners and Social Condition of the White, Coloured, and Negro Population of the West Indies. $2^{\text {nd }}$ ed. Vol. 1. London: Whittaker, 1834. 2 vols. Google Book Search. Web. 29 May. 2011.

Carretta, Vincent. Equiano the African Biography of a Self-Made Man. Athens: $U$ of Georgia P, 2005. Print.

Cugoano, Ottobah. Narrative of the Enslavement of Ottobah Cugoano, a Native of Africa.1787. New York: Penguin, 1999. Print.

Davis, Angela. Reflection on the Black Woman's Role in the Community of Slaves. Black Scholar 3.4, 1971. 2-15. Print.

---. Blues Legacies and Black Feminism: Gertrude "Ma" Rainey, Bessie Smith, and Billie Holliday. New York: Pantheon, 1998. Print.

Davis, Charles T., and Henry Louis Gates, Jr. The Slave's Narrative. New York: Oxford UP, 1985. Print.

Douglass, Frederick. Narrative of the Life of Frederick Douglass. 1845. New York: Penguin, 2002. Print.

Dubey, Madhu. The Politics of Genre in 'Beloved.' Vol. 32, No. 2, Spring 1999. Duke UP, 187-206. JSTOR. Web.15 Aug. 2012. 
Eckstein, Lars. Re-membering the Black Atlantic: On the Poetics and Politics of Literary Memory. Cross/cultures, 84. Amsterdam: Rodopi, 2006. Google Book Search. Web. 1 Jun. 2011.

Equiano, Olaudah. The Interesting Narrative of the Life of Olaudah Equiano, or Gustavus Vassa, the African. Ed. Penguin. 1995 ed. 1789. London: Wilkins, 1789. Print.

Gaines, Ernest. The Autobiography of Miss Jane Pittman. New York: Bantam. 1971. Print.

Gates, Henry L. Talking Black: Critical Signs of the Times. 1988. The Norton Anthology of Theory and Criticism. Ed. Vincent B. Leitch. New York: W.W.Norton \& Company, 2001. 2425-2432. Print.

---. The Signifying Monkey: A Theory of African-American Literary Criticism. 1989. Oxford: Oxford UP. Print.

Genette, Gérard. Narrative Discourse Revisited. Trans. Jane E. Lewin. 1983. Ithaca: Cornell UP, 1988. Print.

Gilroy, Paul. The Black Atlantic: Modernity and Double Consciousness. Cambridge: Harvard UP, 1993. Print.

Greenberg, Kenneth S., ed. The Confessions of Nat Turner and Related Documents. Boston: Bedford, 1996. Print.

Jacobs, Harriet A. Incidents in the Life of a Slave Girl. Ed. Lydia M Child. 2002 ed. 1861. Cambridge: Harvard UP, 2002. Print.

Joannou, Maroula. "'Go West, Old Woman': the radical re-visioning of slave history in Caryl Phillips's Crossing the River." Essays and Studies 2007 (2007): 195+. Academic OneFile. Web. 14 May. 2011.

Hartman, Saidiya. Lose Your Mother. New York: Farrar, 2007. Print.

---. "Venus in Two Acts". Small Axe 12.2 (2008): 1-14. Project MUSE. Web. 9 May 2011.

Hurston, Zora N. Their Eyes Were Watching God. 1937. New York: Harper Collins, 1998. Print. 
Hutcheon, Linda. A Poetics of Postmodernism: History, Theory, Fiction. New York: Routledge, 1988. Print.

Lewis, Matthew G., Esq.MP. Journal of a West India Proprietor Kept During a Residence in the Island of Jamaica. London: Murray, 1834. Google Book Search. Web. 9 Jun. 2011.

Low, Gail. " 'A chorus of common memory': slavery and redemption in Caryl Phillips's Cambridge and Crossing the river." Research in African Literatures 29.4 (1998): 122-41. OmniFile Full Text Mega. Web. 9 Jun. 2011.

Mobley, Marilyn Sanders. "A Different Remembering: Memory, History and Meaning in Toni Morrison's Beloved." Bloom's Modern Critical Views. Ed. Harold Bloom. Chelsea House Publishers, 2005, pg 67-77. Print.

McDowell, Deborah E. Slavery and the Literary Imagination. Baltimore: Johns Hopkins UP, 1989. Print.

Morrison, Toni. Beloved. New York: Penguin, 1988. Print.

Newton, John. The Journal of a Slave Trader, 1750-1754: With Newton's Thoughts upon the African Slave Trade. N.p.: Epworth Press, 1962. Print.

Nugent, Maria. Lady Nugent's Journal Jamaica One Hundred Years Ago. Ed. Frank Cundall. London: Black, 1907. Google Book Search. Web. 11 Nov. 2011.

O'Callaghan, Evelyn. "Historical Fiction and Fictional History: Caryl Phillips's Cambridge," in Journal of Commonwealth Literature, Vol. XXIX, No. 2, 1993, p. 34-47.

Olney, James. "I Was Born': Slave Narratives, Their Status as Autobiography and Literature," in The Slave's Narrative, ed. Charles T. Davis and Henry Louis Gates, Jr. New York: Oxford UP, 1985. Print.

Philip, NourbeSe. Zong!. Middletown: Wesleyan UP. 2008. Print.

Phillips, Caryl. Cambridge. New York: Random House, 1991. Print.

---. Crossing the River. New York: Random House, 1993. Print. 
---. Higher Ground. London: Random House, 2006. Print.

Prince, Mary. The History of Mary Prince, a West Indian Slave. 1831. New York: Penguin, 2002. Print.

Rushdy, Ashraf H.A. Neo-Slave Narratives: Studies in the Social Logic of a Literary Form. Oxford: Oxford UP, 1999. Print.

Russell, Heather. Legba's Crossing: Narratology in the African Atlantic. Athens: $\mathrm{U}$ of Georgia P, 2009. Print.

Ryan, Tim. Calls and Responses. Baton Rouge: Louisiana State UP, 2008. Print.

Schaw, Janet. Journal of a Lady of Quality; Being the Narrative of a Journey from Scotland to the West Indies, North Carolina, and Portugal, in the Years 1774 to 1776. Ed. Evangeline Walker Andrews. New Heaven: Yale UP, 1921. Google Book Search. Web. 14 Nov. 2011.

Selvon, Samuel. The Lonely Londoners. 1956. White Plains: Longman, 2007. Print.

Smith, Valerie. Neo-slave narratives. The Cambridge Companion to the African American Slave Narrative. Ed. Audrey Fisch. Cambridge UP, 2007. 168185. Cambridge Collections Online. Web. 11 April 2011.

Smith, Venture. A Narrative of the Life and Adventures of Venture. 1798. Charleston: Feather Trail P, 2010. Print.

Stepto, Robert B. From Behind the Veil: A Study of Afro-American Narrative. Chicago: $U$ of Illinois $P, 1979$. Print.

Styron, William. The Confessions of Nat Turner. 1967. New York: Vintage, 1992. Print.

Walker, Alice. The Color Purple. 1970. Orlando: Harcourt, 2003. Print.

Walker, Margaret. Jubilee. 1966. New York: First Mariner, 1999. Print.

Washington, Booker T. Up From Slavery. Garden City: Doubleday, 1919. Google Book Search. Web. 14 Nov. 2011. 
White, Hayden. The Content of the Form. Baltimore: Johns Hopkins UP, 1987. Print.

---. Tropics of Discourse. Baltimore: Johns Hopkins UP, 1978. Print.

Wilde, Oscar. The Critic as Artist: With Some Remarks Upon the Importance of Doing Nothing. A Dialogue. Part I. 1881. noiseforlight.com. Web. 22. Sep. 2012. PDF.

Williams, Sherley A. Dessa Rose. New York: Harper, 1986. Print.

Wilson, Harriet E. Our Nig. 1859. New York: Vintage, 2002. Print.

Wright, Richard. Native Son. 1940. New York: Harper Collins, 2005. Print. 